\title{
Overview and preliminary results of the Surface Ocean Aerosol Production (SOAP) campaign
}

\author{
Cliff S. Law ${ }^{1,2}$, Murray J. Smith ${ }^{1}$, Mike J. Harvey ${ }^{1}$, Thomas G. Bell ${ }^{3,4}$, Luke T. Cravigan ${ }^{5,6}$, Fiona C. Elliott ${ }^{1}$, \\ Sarah J. Lawson ${ }^{7}$, Martine Lizotte ${ }^{8}$, Andrew Marriner ${ }^{1}$, John McGregor ${ }^{1}$, Zoran Ristovski ${ }^{6}$, Karl A. Safi ${ }^{9}$, \\ Eric S. Saltzman ${ }^{4}$, Petri Vaattovaara ${ }^{10}$, and Carolyn F. Walker ${ }^{1}$ \\ ${ }^{1}$ National Institute of Water and Atmospheric Research, Wellington, New Zealand \\ ${ }^{2}$ Department of Chemistry, University of Otago, Dunedin, New Zealand \\ ${ }^{3}$ Plymouth Marine Laboratory, Prospect Place, The Hoe, Plymouth, UK \\ ${ }^{4}$ Department of Earth System Science, University of California, Irvine, CA, USA \\ ${ }^{5}$ Climate Science Centre, Commonwealth Scientific and Industrial Research Organisation, Aspendale, Australia \\ ${ }^{6}$ International Laboratory for Air Quality and Health, Queensland University of Technology, Brisbane, Australia \\ ${ }^{7}$ Commonwealth Scientific and Industrial Research Organisation, Oceans and Atmosphere Flagship, Aspendale, Australia \\ ${ }^{8}$ Department of Biology (Québec-Océan), Université Laval, Québec City, Québec, Canada \\ ${ }^{9}$ National Institute of Water and Atmospheric Research, Hamilton, New Zealand \\ ${ }^{10}$ University of Eastern Finland, Kuopio, Finland
}

Correspondence to: Cliff S. Law (cliff.law@niwa.co.nz)

Received: 8 June 2017 - Discussion started: 20 June 2017

Revised: 18 September 2017 - Accepted: 18 September 2017 - Published: 16 November 2017

\begin{abstract}
Establishing the relationship between marine boundary layer (MBL) aerosols and surface water biogeochemistry is required to understand aerosol and cloud production processes over the remote ocean and represent them more accurately in earth system models and global climate projections. This was addressed by the SOAP (Surface Ocean Aerosol Production) campaign, which examined air-sea interaction over biologically productive frontal waters east of New Zealand. This overview details the objectives, regional context, sampling strategy and provisional findings of a pilot study, PreSOAP, in austral summer 2011 and the following SOAP voyage in late austral summer 2012. Both voyages characterized surface water and MBL composition in three phytoplankton blooms of differing species composition and biogeochemistry, with significant regional correlation observed between chlorophyll $a$ and DMSsw. Surface seawater dimethylsulfide (DMSsw) and associated air-sea DMS flux showed spatial variation during the SOAP voyage, with maxima of $25 \mathrm{nmol} \mathrm{L}^{-1}$ and $100 \mu \mathrm{mol} \mathrm{m}^{-2} \mathrm{~d}^{-1}$, respectively, recorded in a dinoflagellate bloom. Inclusion of SOAP data in a regional DMSsw compilation indicates that the current climatological mean is an underestimate for this region of the
\end{abstract}

southwest Pacific. Estimation of the DMS gas transfer velocity $\left(k_{\mathrm{DMS}}\right)$ by independent techniques of eddy covariance and gradient flux showed good agreement, although both exhibited periodic deviations from model estimates. Flux anomalies were related to surface warming and sea surface microlayer enrichment and also reflected the heterogeneous distribution of DMSsw and the associated flux footprint. Other aerosol precursors measured included the halides and various volatile organic carbon compounds, with first measurements of the short-lived gases glyoxal and methylglyoxal in pristine Southern Ocean marine air indicating an unidentified local source. The application of a real-time clean sector, contaminant markers and a common aerosol inlet facilitated multi-sensor measurement of uncontaminated air. Aerosol characterization identified variable Aitken mode and consistent submicron-sized accumulation and coarse modes. Submicron aerosol mass was dominated by secondary particles containing ammonium sulfate/bisulfate under light winds, with an increase in sea salt under higher wind speeds. MBL measurements and chamber experiments identified a significant organic component in primary and secondary aerosols. Comparison of SOAP aerosol number and size distributions 
reveals an underprediction in GLOMAP (GLObal Model of Aerosol Processes)-mode aerosol number in clean marine air masses, suggesting a missing marine aerosol source in the model. The SOAP data will be further examined for evidence of nucleation events and also to identify relationships between MBL composition and surface ocean biogeochemistry that may provide potential proxies for aerosol precursors and production.

\section{Introduction}

It is recognized that the surface ocean alters the properties of the lower atmosphere, and so atmospheric albedo and climate (McCoy et al., 2015; Seinfeld et al., 2016), via the direct and indirect effects of aerosols (O'Dowd and de Leeuw, 2007). Aerosols are precursors of clouds, which play a major role in the scattering and absorption of incident solar radiation (Carslaw et al., 2013), but the concentration, number and chemical properties of aerosols that act as cloud condensation nuclei $(\mathrm{CCN})$ can also influence cloud droplet size and number and consequently precipitation and cloud albedo (Twomey, 1977). Indeed, cloud formation and properties are sensitive to relatively minor changes in aerosol concentration, particularly in remote regions (Carslaw et al., 2013). This is particularly the case in the Southern Ocean, where natural aerosol sources dominate and where $\mathrm{CCN}$ concentrations can range from tens per cubic centimeter in winter to hundreds per cubic centimeter in summer (Andreae and Rosenfeld, 2008), leading to seasonally variant trends in cloud albedo. However, the relationship between clouds and aerosols derived from natural sources is poorly understood, and represents a major uncertainty in the representation of low-level marine clouds and feedbacks in climate models (Wang et al., 2013; Stephens, 2005). Current models underestimate cloud over the Southern Ocean, particularly south of $55^{\circ} \mathrm{S}$, resulting in excess surface shortwave radiation and a warm bias (Trenberth and Fasullo, 2010; Kay et al., 2016). This discrepancy is potentially attributable to a variety of factors, chief among which is the limited understanding of aerosol-cloud interaction and cloud water phase, compounded by a lack of regional observations and data to advance satellite retrievals and climate model simulations.

Breaking waves and associated bubble formation are a major source of primary marine aerosol (PMA), supplying most of the aerosol mass in the marine boundary layer (MBL) over the remote ocean (Andreae and Rosenfeld, 2008) and particularly in regions that experience high winds and breaking waves (de Leeuw et al., 2014). This is reflected in PMA contributing only $\sim 10-20 \%$ of CCN number concentrations over the remote Pacific Ocean (Blot et al., 2013; Clarke et al., 2013) but up to $55 \%$ over the Southern Ocean (McCoy et al., 2015). Although PMA is generally regarded as primarily composed of sea salt, recent reassessments suggest it is highly enriched in organic matter relative to bulk seawater. Organic material may in fact dominate submicron aerosol mass (Facchini et al., 2008; O'Dowd et al., 2004), with the primary organic aerosol (POA) being of biogenic origin and including bacteria, carbohydrates, polymers and gels (Facchini et al., 2008; Russell et al., 2010). Although the contribution of POA to the MBL is uncertain, it may be significant over biologically active oceanic regions, as suggested by correlations between organic aerosol content and surface chlorophyll $a$ (Chl $a$ ) (O'Dowd et al., 2004). There is also similarity in the composition of aerosol and surface ocean organics, and organically enriched submicron particles have been produced experimentally using surface seawater conditions (Quinn and Bates, 2011). Indeed, the degree of organic enrichment may influence both the type and size of aerosols, as well as properties such as aerosol light scattering and water uptake (Vaishya et al., 2012).

It is well-established that biologically productive regions are characterized by elevated concentrations and emissions of a range of compounds that may influence aerosol production, composition and properties (Meskhidze and Nenes, 2010; Gantt and Meskhidze, 2013; de Leeuw et al., 2014). However, the oceanic influence on atmospheric composition is not only attributable to PMAs but also to secondary marine aerosols (SMAs) that are produced during gas-phase reactions of volatile organic compounds (VOCs). Although SMAs have less impact upon aerosol mass, they potentially have a large influence on aerosol number (Meskhidze et al., 2011). The biogeochemical origin of SMAs is reflected in their seasonality, with Aitken and accumulation mode aerosol number concentrations dominated by secondary particles in summertime (Clarke et al., 2013; Cravigan et al., 2015). Research into SMAs has primarily focussed on dimethylsulfide (DMS), the primary natural marine source of volatile sulfur, in response to early hypotheses related to its potential role in climate feedback processes (Charlson et al., 1987). The CLAW hypothesis linked the production of the DMS precursor, dimethylsulfoniopropionate (DMSP), by phytoplankton and subsequent DMS emission and oxidation to sulfate aerosol, to $\mathrm{CCN}$ formation and changes in cloud cover. Although well-studied, this hypothesis remains unproven and there is a lack of consensus, with a recent review identifying uncertainties regarding the role of DMS in aerosol production in the MBL (Quinn and Bates, 2011). However, there is evidence that DMS may play a role in cloud formation over larger spatial and temporal scales, via entrainment from the free troposphere (Carslaw et al., 2010).

The fundamental tenet of the CLAW hypothesis, of feedback between surface ocean biogeochemistry and climate, may be applicable via a broader spectrum of precursor species. Recent research has shown increasing complexity of potential aerosol source pathways, involving a variety of chemical species, processes and interactions (Vaattovaara et al., 2006). In addition to DMS, a variety of other gaseous aerosol precursors that originate from phytoplankton, bacte- 
rial and photochemical sources at the sea surface may undergo physical and chemical transformation to produce new particles in the MBL (Ciuraru et al., 2015). These SMA precursors include volatile organic species, such as carboxylic acids, isoprene, monoterpenes, halocarbons, iodine oxides and iodine (Vaattovaara et al., 2006; Sellegri et al., 2005). A biological source of these SMAs has been inferred from the spatial and temporal correlation between phytoplankton blooms and cloud microphysics (Meskhidze et al., 2009; Meskhidze and Nenes, 2010; Lana et al., 2012). The presence and concentration of SMA precursors in the MBL may be dependent upon plankton abundance and community composition, and consequently their influence on aerosol formation will show spatial and seasonal variability (O'Dowd et al., 2004).

New particle formation may be suppressed by the interaction of aerosol precursors and SMAs with preexisting aerosol, for example, by absorption of ammonia and gaseous sulfuric acid by coarse-mode sea salt aerosol (SSA; Cainey and Harvey, 2002). Conversely, existing particles may grow via condensation, which enhances their $\mathrm{CCN}$ capacity (Clarke et al., 2013). It has also been proposed that organic acids combine with sulfuric acid to create the critical nucleus required for aerosol formation (Zhang, 2010; Almeida et al., 2013). However, nucleation events over the open ocean remain elusive (O'Dowd et al., 2010; Chang et al., 2011; Willis et al., 2016), making it difficult to elucidate the primary pathways and reactants, and consequently they are currently regarded as of low significance to marine aerosol formation. Following nucleation, the aerosol distribution is modified by aerosol-aerosol interaction, heterogenous reactions and removal processes, including coagulation and condensation, resulting in the longest-lived aerosol component being in the accumulation mode $(0.06-0.4 \mu \mathrm{m})$. With such a wide variety of potential precursors and inorganicorganic interactions affecting nucleation and $\mathrm{CCN}$ activation, the modeling of aerosols and their indirect influence on cloud radiative properties over the remote ocean presents a major challenge (Seinfeld et al., 2016).

The production and transfer of aerosol precursors from the ocean surface is also dependent upon physical factors. Exchange across the air-sea interface is primarily controlled by near-surface turbulence, which is dependent on wind and waves. For practical purposes, this is represented by a kinetic factor, the transfer velocity $k$, which is generated with wind speed parameterizations (Nightingale et al., 2000; Ho et al., 2006). Although wind speed provides a reasonable broad-scale proxy for kinetic transfer, other factors such as fetch, wave development, wind-wave direction and surfactants, also influence $k$ and so generate variation in gas exchange and deviation from $k$-wind-speed relationships. For example, most $k$-wind-speed parameterizations do not explicitly capture the solubility effects associated with bubbles (Blomquist et al., 2006), although the COAREG gas transfer model incorporates this factor into a physically based flux algorithm (Fairall et al., 2003, 2011). Biogeochemical gradients near or at the ocean surface are also not considered, despite their potential to alter the air-sea exchange of gases, PMAs and SMAs (Facchini et al., 2008; Calleja et al., 2013).

Previous related research campaigns have examined the biogeochemical and physical factors influencing oceanic DMS and $\mathrm{CO}_{2}$ fluxes, as summarized in Supplement Table S1, but few have linked this to the physical controls of air-sea exchange and variation in the aerosol and trace gas composition of the MBL. Similarly, other campaigns with an atmospheric focus, such as MAP (Marine Aerosol Production; Decesari et al., 2011), have carried out detailed studies of aerosol chemistry but have not interpreted this with regard to surface ocean biogeochemistry. To address this, the Surface Ocean Aerosol Production (SOAP) campaign was initiated, with the primary aim of characterizing the variation in aerosol composition and concomitant marine sources, processes and pathways in the southwest Pacific. SOAP utilized a multidisciplinary framework, encompassing surface ocean biology and biogeochemistry, transport and air-sea exchange with a characterization of aerosol number and composition, to establish controls on aerosols and gas exchange. The campaign consisted of two voyages - a pilot study, PreSOAP, which carried out a regional survey and established sampling strategies, and the following SOAP voyage - in biologically productive frontal waters along the Chatham Rise, east of New Zealand (see Fig. 1). Building upon the approaches used in previous studies, the SOAP campaign targeted three phytoplankton blooms of differing plankton community composition to determine their respective influences on biogeochemistry, gas exchange and MBL composition. This paper details the regional context, sampling strategy, environmental conditions and some preliminary results for the SOAP campaign.

\section{Regional context}

The southwest Pacific has many features in common with the Southern Ocean, as it is characterized by low anthropogenic and terrestrial aerosol loading, long ocean fetch and high wind speed, making it an optimal location for examining the marine contribution to aerosol production. One of its more biologically productive regions lies east of New Zealand, where the subtropical front (STF) extends as a tongue of elevated phytoplankton production (Murphy et al., 2001) along 43.0-43.5 ${ }^{\circ} \mathrm{S}$ over the Chatham Rise (see Fig. 1a). This arises from the confluence of warmer saline subtropical waters that are relatively depleted in macronutrients, with fresher cooler subantarctic waters containing elevated macronutrients but being depleted in iron (see Fig. 1b; Boyd et al., 1999). Mixing across the front alleviates nutrient stress, which, combined with a relatively stable water column, promotes primary production (Chiswell et al., 2013). Ocean color climatologies show a monthly mean Chl $a$ of $0.6 \mathrm{mg} \mathrm{m}^{-3}$, reaching $\sim 1 \mathrm{mg} \mathrm{m}^{-3}$ over the Chatham Rise in spring (Murphy et 
(a)

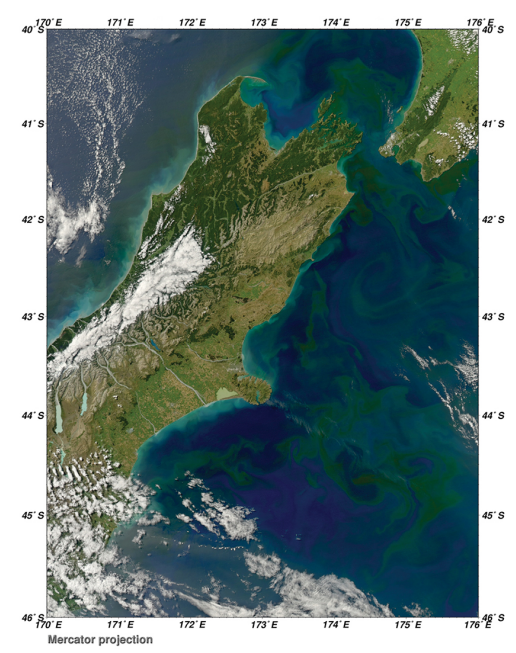

(b)

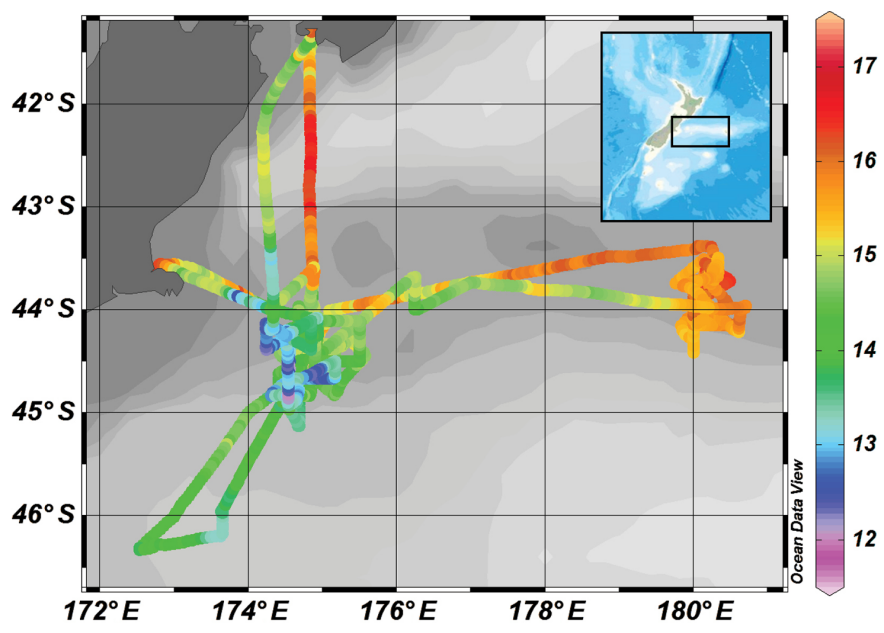

Figure 1. (a) An ocean color image (10/2/11) during the PreSOAP voyage, showing phytoplankton blooms on the western Chatham Rise region along $44^{\circ} \mathrm{S}$ (data courtesy of NASA). (b) The SOAP voyage track in the Chatham Rise region, overlain by sea surface temperature $\left({ }^{\circ} \mathrm{C}\right)$, with the study region (box) indicated in the inset bathymetric map of New Zealand.

al., 2001), and the region is characterized by elevated marine particle export, secondary production and fish stocks (Nodder et al., 2007; Bradford-Grieve et al., 1999). In spring the phytoplankton community composition varies with water mass, with diatoms dominating the STF, cryptophytes, prasinophytes and dinoflagellates being more prevalent in subtropical waters, and photosynthetic nanoflagellates dominating subantarctic waters (Chang and Gall, 1998; Delizo et al., 2007). The STF also supports spatially extensive coccolithophore blooms (Sadeghi et al., 2012) and is situated on the northern edge of the "Great Calcite Belt" (Balch et al., 2011), a latitudinal band of elevated backscatter attributed to coccolithophore liths. Surface mixed layer nutrients vary spatially in response to mixing of the water masses and seasonally due to phytoplankton uptake, with the evolution of nutrient stoichiometry and grazing determining the succession and duration of different phytoplankton blooms (Chang and Gall, 1998; Delizo et al., 2007). The STF is characterized by significant gradients in $p \mathrm{CO}_{2}$ associated with phytoplankton blooms, with current global climatologies indicating the region east of New Zealand as a significant carbon sink (> $1 \mathrm{~mol} \mathrm{C} \mathrm{m}^{-2} \mathrm{yr}^{-1}$; Landschuetzer et al., 2014).

The waters south of New Zealand are characterized by high wind speeds, which drive the disproportionate contribution of this region to global ocean $\mathrm{CO}_{2}$ uptake. Here, wind, waves and currents develop unhindered by land, and strong persistent westerlies act over long fetch to generate large swells that propagate northeast influencing the wave climate off New Zealand. While this wave energy is attenuated closer to land in the eastern Chatham Rise, the average wave energy is still $75 \%$ of values south of New Zealand, where annual mean wave heights exceed $4 \mathrm{~m}$. Subantarctic waters south of the Chatham Rise region provided a prime location for a dual tracer release experiment (SAGE; Harvey et al., 2011), aimed at constraining $k$ at high wind speeds. Comparison of the SAGE $k$-wind-speed parameterization with those generated in other regions and using different techniques showed generally good agreement (Ho et al., 2006); this may be interpreted as indicating that regional influences on exchange may be less important, supporting the application of a universal wind speed parameterization. Nevertheless, other factors, such as wave age, duration and height do influence gas exchange in this region (Smith et al., 2011; Young et al., 2012). The elevated winds also influence the transfer of aerosols and precursors, as reflected by a zonal band of elevated sea spray aerosol mass and water-insoluble organic matter over the Chatham Rise region (Vignati et al., 2010).

Both models and measurements indicate that DMS is a significant contributor to total non-sea-salt sulfate $\left(\mathrm{nssSO}_{4}\right)$ in the Southern Hemisphere (Gondwe et al., 2003; Korhonen et al., 2008). However, a paucity of observational data in the Southern Ocean has hindered the development of global climatologies for surface seawater DMS (DMSsw), with the region southeast of New Zealand represented by only a few data points in a recent DMS climatology (Lana et al., 2011). Despite this shortcoming, this climatology provides a realistic representation of atmospheric DMS and total sulfate when applied in aerosol-climate global climate models, particularly over the Southern Ocean (Mahajan et al., 2015). Seasonal variability in atmospheric DMS is apparent at stations around New Zealand and south of $44^{\circ} \mathrm{S}$ (Blake et al., 1999), with concentrations of 100-200 pptv and maximal values associated with the transport of DMS from waters to the south in summer (Harvey et al., 1993; de Bruyn et al., 


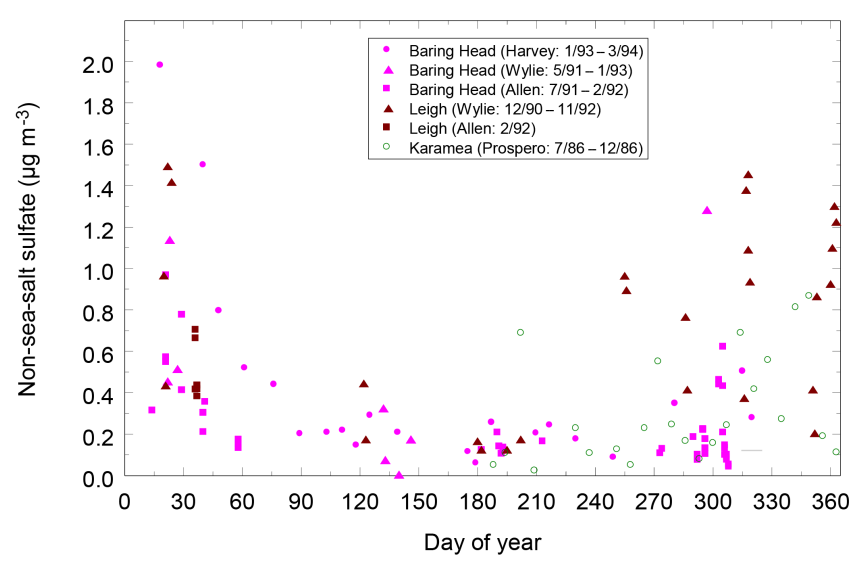

Figure 2. Non-sea-salt sulfate concentrations plotted against day of year at different New Zealand coastal atmospheric monitoring sites.

2002; Wylie and de Mora, 1996). Corresponding seasonality in $\mathrm{nssSO}_{4}$ was observed, with a maximum $\left(0.8-1.5 \mu \mathrm{g} \mathrm{m}^{-3}\right)$ in early austral summer at the start of the year, decreasing in late summer to $0.1-0.4 \mu \mathrm{g} \mathrm{m}^{-3}$ through autumn and winter (see Fig. 2; Sievering et al., 2004; Allen et al., 1997). For comparison, coarse SSA dominates the aerosol mass at Baring Head, with concentrations of 6-10 $\mu \mathrm{g} \mathrm{m}^{-3}$ (Jaeglé et al., 2011; Spada et al., 2015). Similar seasonal cycles of DMS and $\mathrm{nssSO}_{4}$ were recorded at Cape Grim (Ayers, 1991), and the observed diurnal inverse correlation between sulfur dioxide and DMS at Baring Head was applied to estimate yield and the potential contribution to aerosols (de Bruyn et al., 2002). Consistent seasonal trends between activated particles and cloud droplet number concentration were also apparent, with a summer maximum over the Southern Hemisphere (Boers et al., 1996, 1998), related to phytoplankton production (Thomas et al., 2010). Overall, the temporal trends in aerosol precursors and pathways do not follow that of wind speed and other physical drivers but instead reflect biological processes inferring control by surface ocean biogeochemistry (Korhonen et al., 2008).

\section{Research programme and strategy}

\subsection{PreSOAP}

A pilot study, PreSOAP, was carried out to test technical approaches and confirm the regional source of biogenic aerosols in the Chatham Rise region on the New Zealand research vessel, Tangaroa, on 1-12 February 2011 (day of year, DoY, 32-42). The strategy of bloom location using satellite imagery and subsequent mapping of surface properties proved successful, with three blooms of differing DMSsw and $p \mathrm{CO}_{2}$ signatures located and monitored each for 34 days. The first bloom was initially dominated by dinoflagellates with an increase in diatom biomass after 3 days, while the second and third blooms were primarily dominated by coccolithophores and dinoflagellates, respectively. This variability in species composition resulted in significant spatial and temporal variability in DMS concentrations in the MBL (DMSa) and DMSsw. DMSa concentration varied over 2 orders of magnitude, reaching 1000 ppt on DoY 36 (see Fig. 3b), similar in range to that recorded at the Baring Head station near Wellington (Harvey et al., 1993; de Bruyn et al., 2002). There was no significant correlation between DMS in the two phases, with DMSa showing a stronger relationship with wind speed (see Fig. 3). Surface Chl $a$ concentrations reached $2 \mathrm{mg} \mathrm{m}^{-3}$, but there was no significant relationship between DMSsw and $\mathrm{Chl} a$, with the DMSsw maximum of $\sim 10 \mathrm{nmol} \mathrm{L}^{-1}$ during the first bloom coinciding with an intermediate Chl $a$ of $\sim 1 \mathrm{mg} \mathrm{m}^{-3}$ (Fig. 3d). The observed temporal and spatial variability in DMSa and DMSsw during PreSOAP highlighted the technical challenge of establishing relationships between surface ocean biogeochemistry and atmospheric composition. Provisional method development was also carried out for the measurement of DMS and other parameters in near-surface waters and the sea surface microlayer (SSM).

Surface DMSsw and $p \mathrm{CO}_{2}$ were mapped, and DMSa and $\mathrm{CO}_{2} \mathrm{MBL}$ concentrations and fluxes were measured continuously by sensors and collectors mounted on the bow of the vessel. Testing of the eddy covariance (EC) flux technique identified an issue with water vapor interference that dominated the $\mathrm{CO}_{2}$ signal recorded by an open-path infrared gas analyzer (IRGA). Preliminary studies also identified that residual ship motion dominated over turbulence for the realtime switching of relaxed eddy accumulation measurement of flux under high swell conditions. The logistical challenges of flux measurement at distance from the vessel were also assessed by deployment of a free-floating catamaran supporting a mounted gradient flux sampling system (Smith et al., 2017). A temperature microstructure profiler was also deployed to record near-surface temperature and turbulence structure (Stevens et al., 2005), although this was limited to short sampling periods, highlighting the need for a mounted thermistor array on a spar buoy for longer measurement coverage.

The utility of a baseline sector for sampling MBL composition, using relative wind direction and speed, was also tested during PreSOAP. Measurements showed a tendency for higher condensation nuclei concentration in the "nonbaseline" sector, confirming the utility of this approach (Harvey et al., 2017). A common aerosol inlet provided clean air from a height of $17.5 \mathrm{~m}$ above sea level to instruments and sensors in a container laboratory on deck. Particle size distribution and concentration, including ultrafine nuclei concentrations, were continuously monitored using a scanning mobility particle sizer (SMPS) and optical particle counters (OPCs), with bulk ion chemistry samples collected using a high-volume sampler. The composition of primary marine aerosols was also examined using a $0.45 \mathrm{~m}^{3}$ bubble chamber, in which sea spray was formed via the bursting of bubbles 

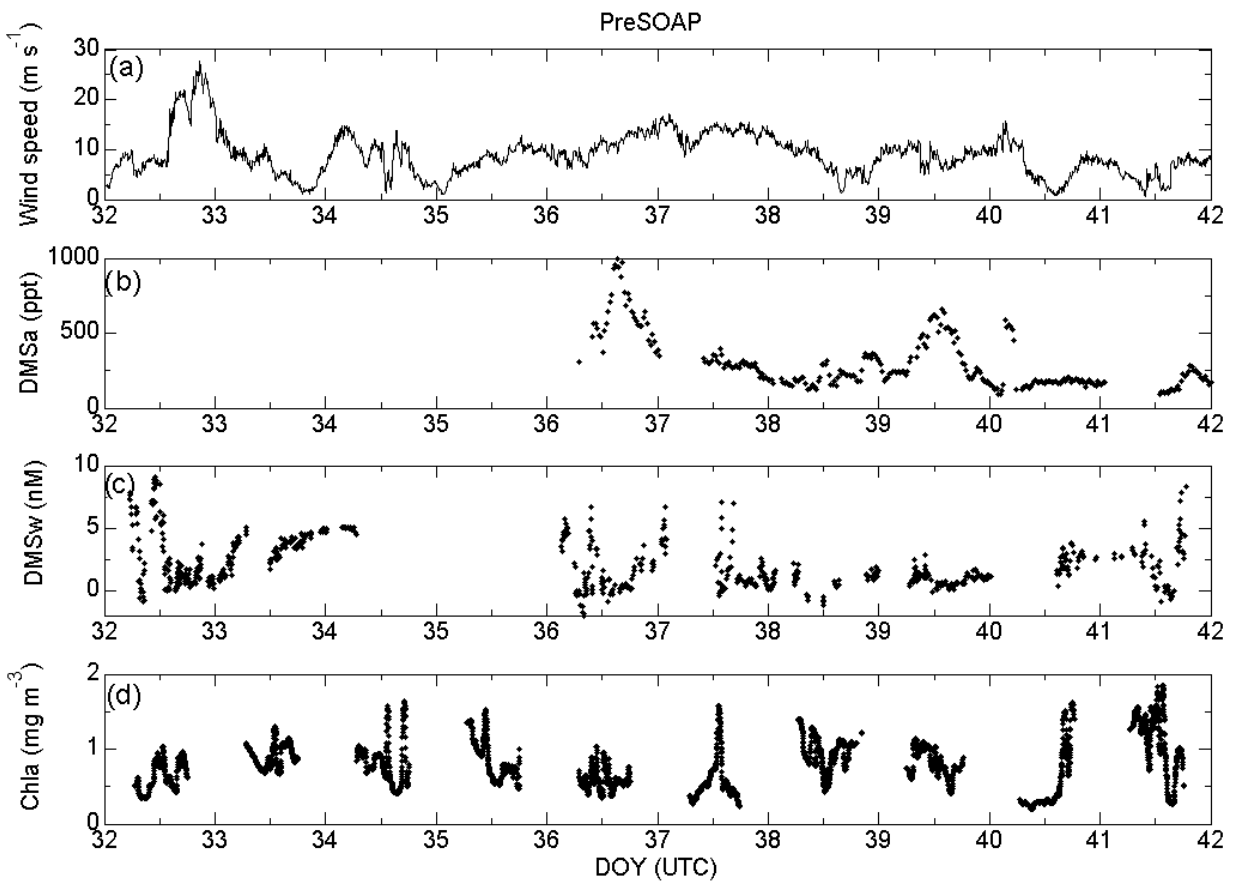

Figure 3. Continuous measurements during PreSOAP of (a) wind speed $\left(\mathrm{m} \mathrm{s}^{-1}\right)$, (b) atmospheric DMS (ppt), (c) surface water DMS (nmol L $\left.{ }^{-1}\right)$ and (d) surface chlorophyll $a\left(\mathrm{mg} \mathrm{m}^{-3}\right.$; quenched data removed).

produced by passing clean compressed air through sintered glass (Mallet et al., 2016).

\subsection{The SOAP voyage}

The SOAP voyage employed the strategy successfully piloted on PreSOAP of identifying phytoplankton blooms in NASA MODIS Aqua and Terra satellite ocean color images with subsequent bloom location and mapping using a suite of underway sensors (Chl $a, \beta_{660}$ backscatter, $p \mathrm{CO}_{2}$, DMSsw). The blooms were discrete and coherent areas of elevated ocean color that were provisionally characterized by a concentration of $1 \mathrm{mg} \mathrm{m}^{-3} \mathrm{Chl} a$ or higher. For each bloom, a nominal center was identified, based upon maximum DMSsw and Chl $a$ concentrations, and marked by deployment of a spar buoy. Repeat activities at the bloom center included the characterization of the surface mixed layer by vertical profiling, the collection of SSM samples at a distance from the main vessel and gradient flux on a catamaran. Overnight mapping was carried out to determine changes in bloom magnitude and position. Sampling also took place at stations on the periphery and outside the blooms, as defined by distance from the bloom center and a clear demarcation in surface biogeochemical variables. The SOAP voyage was nominally divided into three different bloom periods (see Fig. 4), with an initial dinoflagellate bloom (B1) located $12 \mathrm{~h}$ into the SOAP voyage that exhibited elevated $\mathrm{Chl} a$ and DMSsw and $p \mathrm{CO}_{2}$ drawdown, a coccolithophore bloom (B2) with initially moderate signals that weakened, and a fi- nal bloom (B3) of mixed community composition. Following a storm, the surface water column structure and biogeochemistry were significantly different, and so this bloom was subdivided into $\mathrm{B} 3 \mathrm{a}$ and $\mathrm{B} 3 \mathrm{~b}$.

\subsubsection{Environmental conditions during the SOAP voyage}

Back-trajectory analysis of particle density was calculated for each bloom using the Lagrangian Numerical Atmospheric-dispersion Modelling Environment (NAME) for the lower atmosphere (see Fig. 5). The meteorological situation evolved over the SOAP voyage from a high-pressure system with light winds during B1, to stronger winds during B2 and B3. The main weather features included a depression crossing the central South Island on DoY 54-55 during B2 and a second depression from the east from DoY 58 onwards. During B3, a vigorous front advanced up the east coast of the South Island on DoY 61 with strong SW winds of $20 \mathrm{~m} \mathrm{~s}^{-1}$, followed by a depression crossing the lower North Island on DoY 63 that maintained a fresh southerly airflow for the remainder of the voyage. Air and water temperatures during B1were generally similar indicating near-neutral stability, whereas B2 experienced a period of warm, moist air and reversal in direction of turbulent heat fluxes, followed by a short period when air temperatures were $2-3^{\circ} \mathrm{C}$ higher on DoY 56-58 (See Fig. 6). Waves were dominated by swell from the south-southwest, with significant wave height mirroring trends in wind speed, reaching a $5 \mathrm{~m}$ maximum dur- 

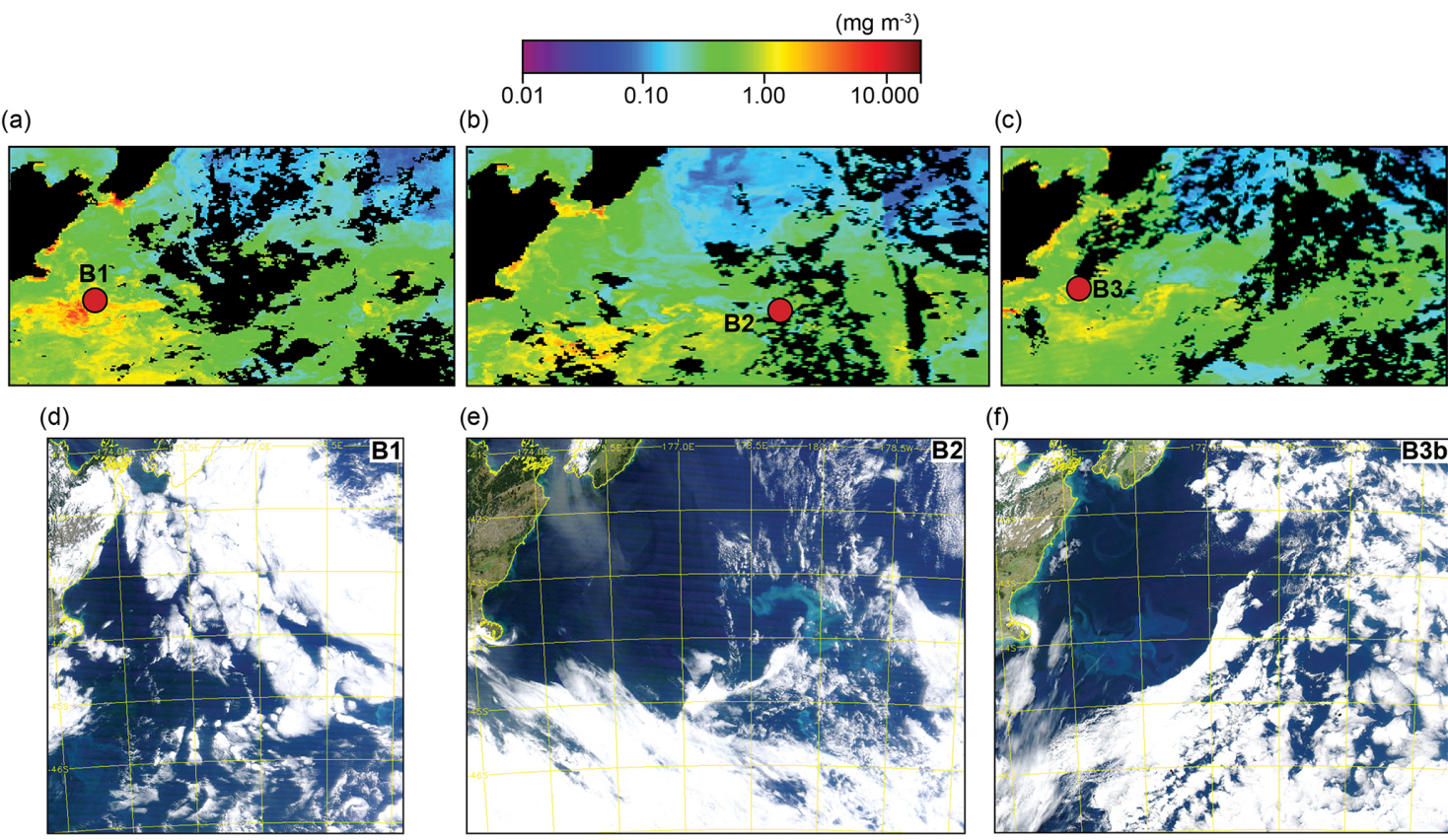

(e)

(f)
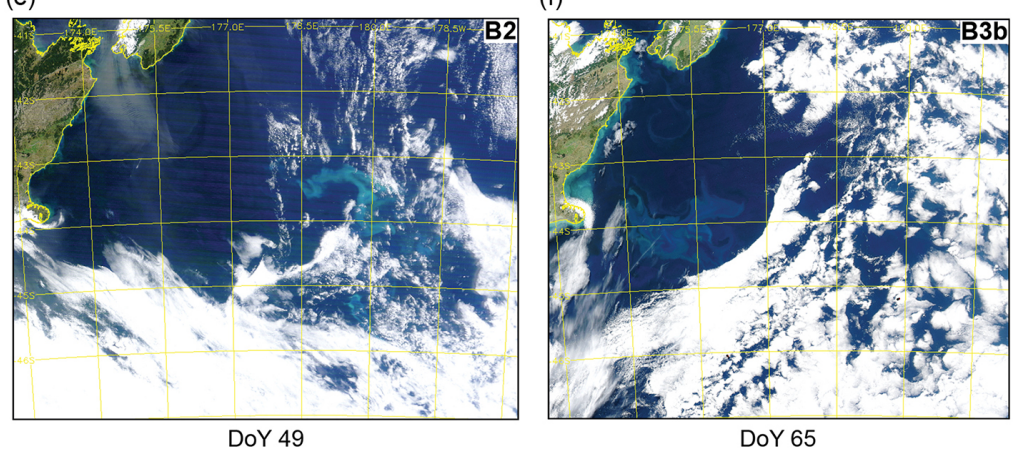

Figure 4. Eight-day composite images of surface chlorophyll $a$ (MODIS, $4 \mathrm{~km}$ resolution) during the SOAP voyage for (a) 10-17 February 2012 (DoY 41-48), (b) 18-25 February 2012 (DoY 49-56) and (c) 26 February-4 March (DoY 57-64), showing bloom locations (red dots), with the color scale $\left(\mathrm{mg} \mathrm{m}^{-3}\right.$ ) above figures (a-c), and daily true-color images for (d) Bloom 1 (16 February 2012, DoY 47), (e) Bloom 2 (18 February 2012, DoY 49) and (f) Bloom 3 (3 March, DoY 65) (MODIS Aqua data courtesy of NASA).

ing the localized storm on DoY 61 (see Fig. 6). Wave parameters obtained from NOAA WaveWatch III analyses indicated that wave height was $23 \%$ lower during B1 and B3 and $13 \%$ lower during B2, relative to wave height south of New Zealand at $50^{\circ} \mathrm{S}$.

Table 1 summarizes the hydrographic and biogeochemical characteristics in the surface mixed layer of the three phytoplankton bloom regions. B1 was a large dinoflagellate bloom with high surface DMSsw (maximum $\sim 30 \mathrm{nmol} \mathrm{L}^{-1}$; mean $16.8 \mathrm{nmol} \mathrm{L}^{-1}$; Bell et al., 2015) and Chl $a$ (maximum $3.4 \mathrm{mg} \mathrm{m}^{-3}$ ) and significant $\mathrm{CO}_{2}$ undersaturation with a mean surface $p \mathrm{CO}_{2}$ of $320 \mathrm{ppmv}$ (see Table 1). B1 was located south of the Mernoo bank, a deep channel between the western end of Chatham Rise and the east coast of the South Island. This region has been previously identified as a prime location for phytoplankton blooms, due to eddy-driven mixing and flow reversals arising from current and topographic interaction, which enhance iron and nutrient supply (Boyd et al., 2004). During B1, winds remained light (see Table 1) with a calm sea state, and the spar buoy drifted northeast primarily under the action of surface currents. Solar irradiance was high and a shallow surface mixed layer developed (see Fig. 6), with a significant near-surface temperature gradient (Walker et al., 2016). Mean nitrate and phosphate concentrations (5.3 and $0.4 \mu \mathrm{mol} \mathrm{L} \mathrm{L}^{-1}$, respectively) were sufficient for phytoplankton growth, whereas silicate was low (see Table 1) and close to growth-limiting concentrations
(Boyd et al., 1999). Although dinoflagellates dominated, coccolithophore biomass was higher at some stations, and nanoeukaryote abundance was generally low. B1 was occupied for 5-6 days, during which broader regional excursions with overnight mapping identified a bloom of high $\mathrm{Chl} a$ but relatively low DMSsw to the southwest.

The vessel relocated to a coccolithophore bloom, B2, evident at the eastern end of the Chatham Rise in MODIS true-color satellite images (see Fig. 4b). Upon arrival on DoY 52, B2 showed an initial mean DMSsw of $9 \mathrm{nmol} \mathrm{L}^{-1}$ and elevated Chl $a$ and was characterized by a relatively warmer, shallower, saltier surface mixed layer of lower nitrate concentration (compared to B1; see Table 1), typical of subtropical water. This appeared to provide optimal conditions for coccolithophores as surface water backscatter $\left(\beta_{660}\right)$ was initially elevated by high lith abundances, with coccolithophores accounting for up to $40 \%$ of phytoplankton carbon. However, the intrusion of warm, moist air associated with northwesterly winds, coincided with a reversal in the direction of turbulent heat fluxes and was followed by a southwest wind shift strengthening to $17 \mathrm{~m} \mathrm{~s}^{-1}$ by DoY 56 (see Fig. 6). This resulted in deepening and cooling of the surface mixed layer with a corresponding increase in nutrient concentrations, which, combined with a decrease in solar irradiance, resulted in a decline in Chl $a$ and DMSsw (Bell et al., 2015). 


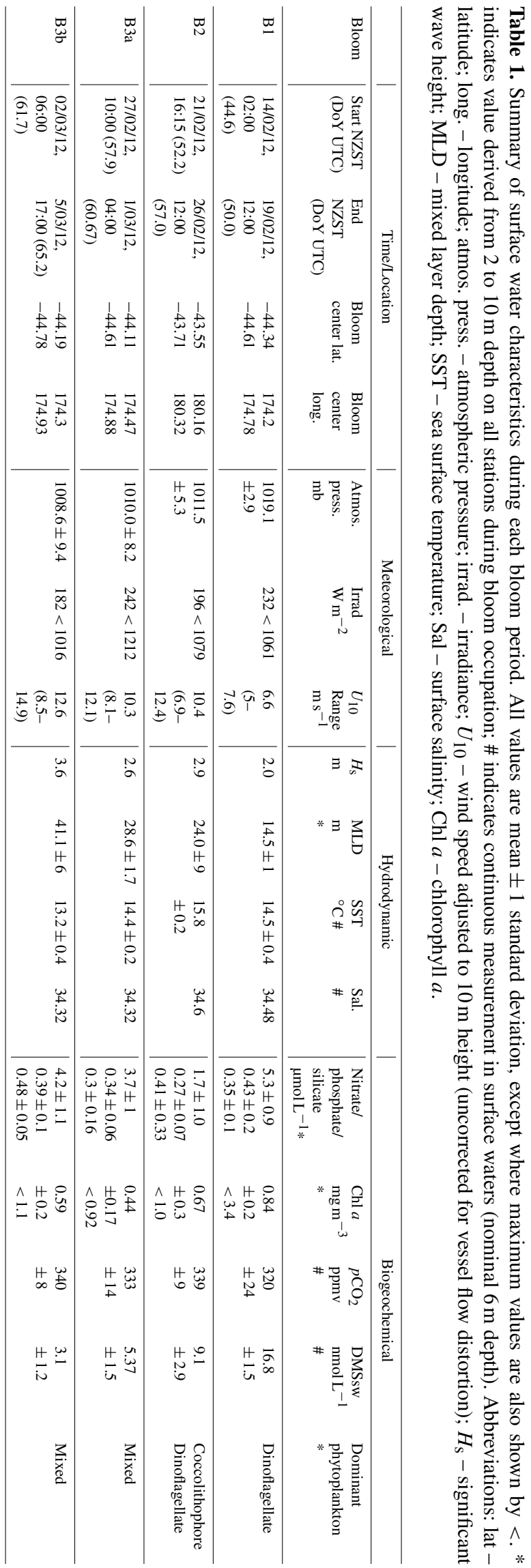




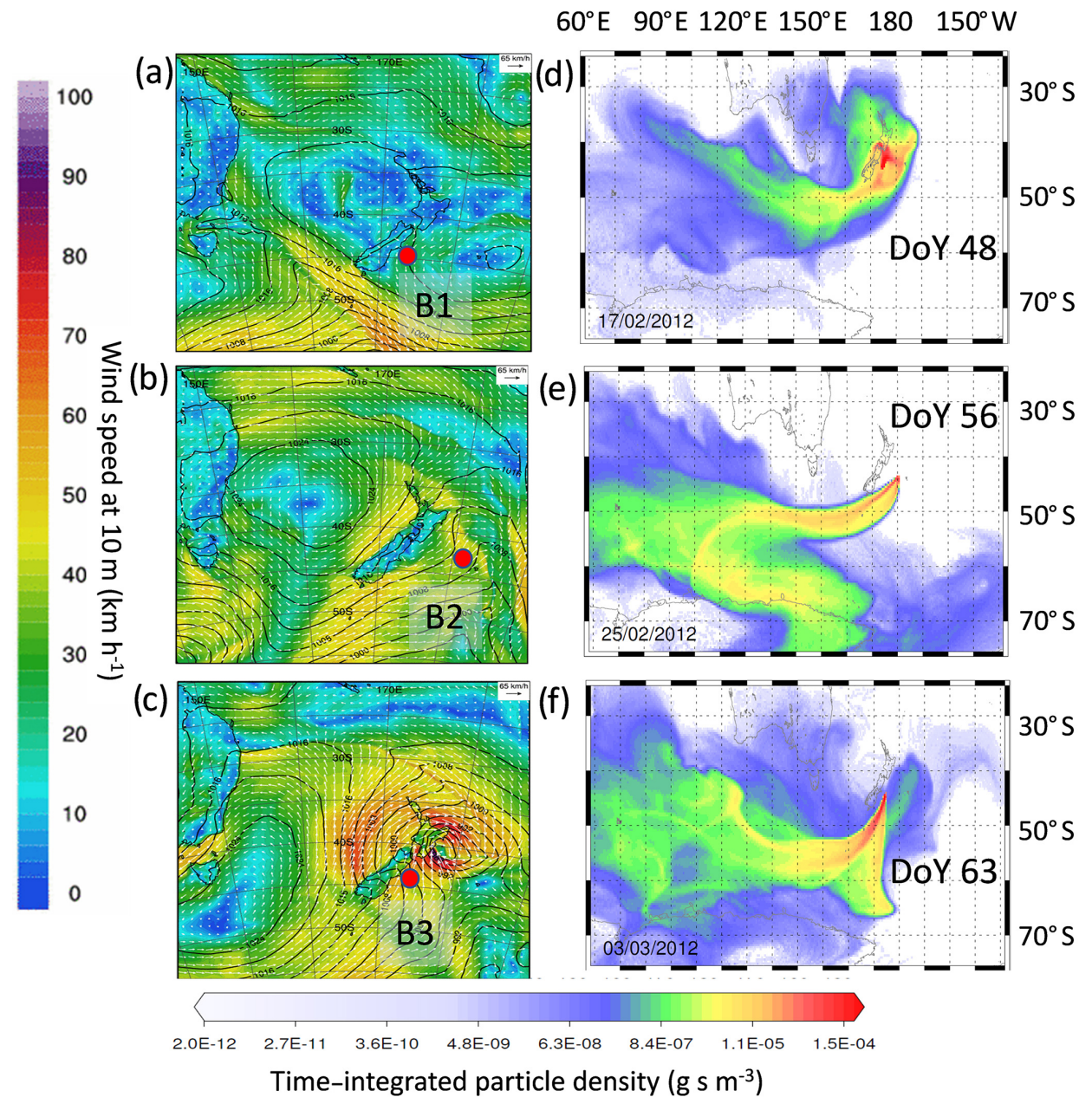

Figure 5. (a-c) Synoptic meteorology summary for each bloom period during the SOAP voyage. Surface pressure and wind plots (color scale to the left of panels $\mathbf{a}-\mathbf{c}$ ) are derived from the New Zealand local area unified model NZLAM, with the bloom location indicated by a red dot. (d-f) Back-trajectory analyses for each bloom period during the SOAP voyage. This was calculated using the Lagrangian Numerical Atmospheric-dispersion Modelling Environment (NAME) for the lower atmosphere $(0-100 \mathrm{~m})$ as time-integrated particle density $\left(\mathrm{g} \mathrm{sm}^{-3}\right.$; color scale below figures). Each plot shows the back trajectory of eight "releases", i.e., one every $3 \mathrm{~h}$ over $24 \mathrm{~h}$ for the actual ship position.

Following the 5-day occupation of B2, the vessel returned to south of Mernoo bank to assess a bloom that had developed near the original site of B1. Surface biogeochemical signals were initially weak in B3a, with a mixed community of coccolithophores and dinoflagellates and low DMSsw $\left(2.2 \mathrm{nmol} \mathrm{L}^{-1}\right)$ and $\mathrm{Chl} a$ (mean $\left.0.39 \mathrm{mg} \mathrm{m}^{-3}\right)$. However, an intense front advanced up the South Island and resulted in strong SW winds that exceeded $20 \mathrm{~ms}^{-1}$ (see Fig. 6), after which mixed layer depth and associated nutrients increased. Consequently, stations before and after the storm were physically and biogeochemically disparate. B3a stations exhibited similar sea surface temperature to B1, but with a deeper surface mixed layer and a Chl $a$ half that of B1, whereas B3b stations were significantly cooler $\left(\right.$ at $\left.13^{\circ} \mathrm{C}\right)$ and deeper $(41 \mathrm{~m})$ than B1 (see Fig. 7), with higher silicate concentration due to enhanced vertical mixing. Subsequent stabilization of the surface mixed layer by light winds combined with elevated nutrients stimulated $\mathrm{Chl} a$, diatom and coccolithophore abundance in the final B3b stations (see Figs. 6 and 7)

\section{SOAP work programmes and observations}

A number of parameters were measured (see Table 2) in three interlinked work programmes during the SOAP voyage, as indicated in Fig. 8 and detailed below.

\subsection{The distribution and composition of aerosols, precursors and trace gases in the MBL}

Aerosol number concentration, size distribution, composition, water uptake and $\mathrm{CCN}$ concentration were measured semicontinuously during SOAP to address the overall paucity of aerosol observations and the apparent rarity of nucleation events over the remote ocean. These were char- 
Table 2. Parameters sampled during the SOAP voyage. Key: C - continuous; D - discrete; W - workboat; *indicates instrument sampling on common aerosol inlet.

\begin{tabular}{|c|c|c|}
\hline Measurement & Mode & Instrument \\
\hline \multicolumn{3}{|l|}{ WP1 Atmospheric } \\
\hline Organic nuclei production & $\mathrm{C}^{*}$ & $\begin{array}{l}\text { Ultrafine organic tandem differential mobility analyzer (UFO- } \\
\text { TDMA) }\end{array}$ \\
\hline Aerosol water uptake and volatility & $\mathrm{C}^{*}$ & $\begin{array}{l}\text { Volatility humidity differential mobility analyzer (VH- } \\
\text { TDMA) }\end{array}$ \\
\hline Nucleation/Aitken mode size spectra & $\mathrm{C}^{*}$ & Scanning mobility particle sizer (SMPS) \\
\hline Condensation nuclei counts & $\mathrm{C}^{*}$ & Condensation particle counter (CPC) \\
\hline Accumulation mode aerosol number & $\mathrm{C}$ & Passive cavity aerosol spectrometer probe (PCASP) \\
\hline Cloud condensation nuclei & $\mathrm{C}^{*}$ & $\mathrm{CCN}$ spectrometer \\
\hline Aerosol filter chemistry - major ions & $\mathrm{C}$ & Hi-vol, cascade, ion chromatograph \\
\hline Black carbon & $\mathrm{C}^{*}$ & Aetholometer \\
\hline $\mathrm{PM}_{10}$ aerosol filters & $\mathrm{C}$ & $\begin{array}{l}\text { Organic functional groups by FTIR and inorganic composition } \\
\text { by ion beam analysis }\end{array}$ \\
\hline Column aerosol & $\mathrm{D}$ & Sun photometer (Microtops II) \\
\hline $\begin{array}{l}\text { Nascent sea spray composition via bubble burst of seawater } \\
\text { samples }\end{array}$ & $\mathrm{D}$ & Chamber experiments \\
\hline DMS & $\mathrm{C}$ & MesoCIMS (chemical ionization mass spectrometry) \\
\hline $\mathrm{CO}_{2}$ and methane & $\mathrm{C}$ & Picarro CRDS \\
\hline Halocarbons, iodine and halogen oxides & $\mathrm{C}$ & $\begin{array}{l}\mu \text {-Dirac electron capture detector-gas chromatograph and } \\
\text { multi-axis differential optical absorption spectroscopy (Max- } \\
\text { DOAS) }\end{array}$ \\
\hline $\begin{array}{l}\text { VOCs (acetone, DMS, acetonitrile, methanol, methanethiol, } \\
\text { isoprene, monoterpenes, acetaldehyde) }\end{array}$ & $\mathrm{C}$ & Proton transfer reaction mass spectrometer (PTR-MS) \\
\hline VOCs $C_{5}$ to $C_{15}$ & $\mathrm{D}$ & Pre-concentration and TD-GC-FID/MS \\
\hline Aldehydes, ketones (incl. dicarbonyls), $\mathrm{C}_{2}$ to $\mathrm{C}_{8}$ & $\mathrm{D}$ & Derivatization and HPLC \\
\hline \multicolumn{3}{|l|}{ WP2 physics } \\
\hline DMS flux & $\mathrm{C}$ & MesoCIMS (chemical ionization mass spectrometry) \\
\hline $\mathrm{CO}_{2}$ EC flux & $\mathrm{C}$ & $\begin{array}{l}\text { LI-COR infrared gas analyser (IRGA), sonic anemometer mo- } \\
\text { tion sensors }\end{array}$ \\
\hline DMS gradient flux & $\mathrm{D}$ & Catamaran, SCD-GC \\
\hline Near-surface $\mathrm{T}$ and $\mathrm{S}$ & $\mathrm{D}$ & Conductivity-temperature-depth (CTD) \\
\hline Near-surface stratification & $\mathrm{C}$ & Spar buoy - temperature array, microcats \\
\hline Near-surface turbulence & $\mathrm{C}$ & Vector, FastCat \\
\hline Sea state & $\mathrm{C}$ & NOAA Wavewatch III \\
\hline Whitecap coverage & $\mathrm{D}$ & Campbell Scientific 5-megapixel Camera \\
\hline Meteorological conditions & $\mathrm{C}$ & Automatic weather station (AWS) \\
\hline Bulk fluxes & $\mathrm{C}$ & $\begin{array}{l}\text { Eppley radiometers, rain gage; Eppley Precision Spectral } \\
\text { Pyranometer (PSP) }\end{array}$ \\
\hline MBL height and stability & $\mathrm{D}$ & Radiosonde \\
\hline \multicolumn{3}{|l|}{ WP3 ocean biogeochemistry } \\
\hline Chlorophyll $a$ & $\mathrm{C}, \mathrm{D}, \mathrm{W}$ & Ecotriplet \\
\hline Backscatter and $\beta_{660}$ backscatter & $\mathrm{C}$ & Ecotriplet \\
\hline$p \mathrm{CO}_{2}$ & $\mathrm{C}$ & IRGA \\
\hline $\mathrm{pH}$ & $\mathrm{C}, \mathrm{D}, \mathrm{W}$ & Spectrophotometer \\
\hline Dissolved inorganic carbon (DIC) & $\mathrm{D}$ & \\
\hline Nutrients & $\mathrm{D}, \mathrm{W}$ & Colorimetric autoanalyzer \\
\hline Dissolved organic carbon (DOC) & $\mathrm{D}, \mathrm{W}$ & High-temperature catalytic oxidation (HTCO) \\
\hline CDOM & $\mathrm{D}, \mathrm{W}$ & Spectrophotometer \\
\hline $\begin{array}{l}\text { Particulate organic and total carbon and nitrogen and isotopes } \\
\left(\mathrm{POC} / \mathrm{PON} / \mathrm{PC} / \mathrm{PN} /{ }^{13} \mathrm{C} /{ }^{15} \mathrm{~N}\right)\end{array}$ & $\mathrm{D}$ & Mass spectrometer \\
\hline Fatty acids and alkanes & $\mathrm{D}, \mathrm{W}$ & \\
\hline Dissolved DMS & $\mathrm{C}$ & MiniCIMS (chemical ionization mass spectrometry) \\
\hline Dissolved DMS & $\mathrm{D}, \mathrm{W}$ & SCD/FPD (flame photometric detector) \\
\hline DMSP and processes & $\mathrm{D}, \mathrm{W}$ & SCD \\
\hline Pigments & $\mathrm{D}$ & HPLC \\
\hline Microbial community abundance & $\mathrm{D}, \mathrm{W}$ & Flow cytometry \\
\hline Phytoplankton identification/counts & $\mathrm{D}, \mathrm{W}$ & Optical microscopy \\
\hline Microzooplankton & $\mathrm{D}, \mathrm{W}$ & Optical microscopy \\
\hline
\end{tabular}




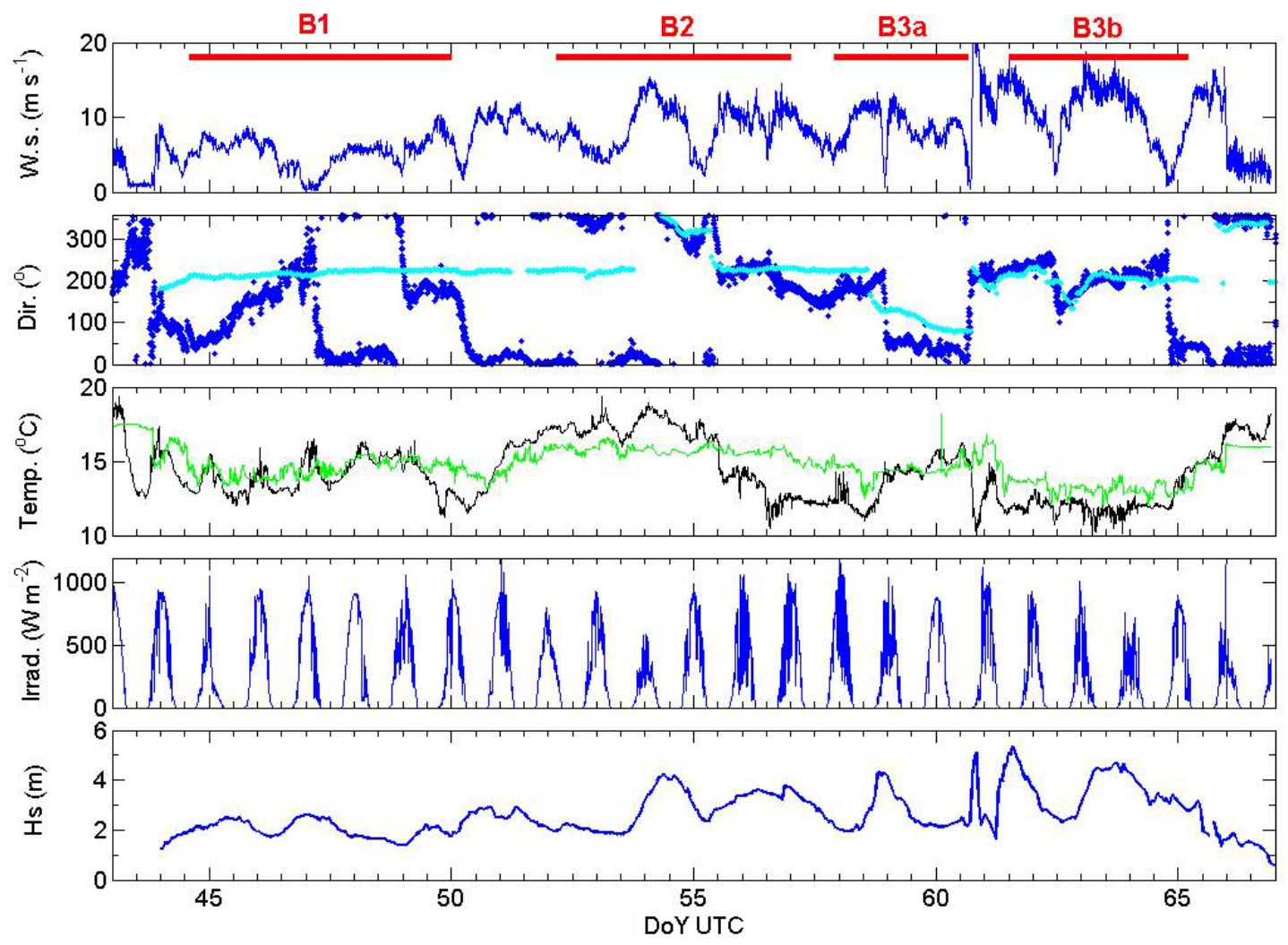

Figure 6. Meteorological and hydrodynamic variables during the SOAP voyage, including (a) wind speed (W.s., $\mathrm{ms}^{-1}$ ); (b) direction (Dir., ${ }^{\circ}$ ); wind (blue) and wave (cyan); (c) temperature (Temp., $\left.{ }^{\circ} \mathrm{C}\right)$; air (black) and surface water (green); (d) irradiance (Irrad., $\mathrm{W} \mathrm{m}^{-2}$ ) and (e) significant wave height $\left(H_{\mathrm{s}}, \mathrm{m}\right)$. Bloom occupation periods are indicated by the red horizontal bars and bloom labels in the upper panel.

acterized by a suite of instruments covering a particle size range of 0.01 to $10 \mu \mathrm{m}$ (see Fig. 9 and Table 2), which enabled the determination of the size-dependent contribution of PMA and nssSO 4 to aerosol and CCN concentrations. Aerosol characterization identified variable Aitken and consistent submicron-sized accumulation and coarse modes, with the submicron aerosol mass dominated by secondary aerosol with ammonium sulfate/bisulfate under light winds and with an increase in sea salt proportion as local winds increased. Ongoing data analysis is examining whether significant nucleation events occurred.

The operational mode for underway aerosol measurement was to slowly steam at $1-2 \mathrm{kn}$ into the prevailing wind, across an area of high biological productivity or a significant air-sea gas gradient, generally between noon and 14:00 when solar irradiance was maximal. The common aerosol inlet developed during PreSOAP allowed uncontaminated air from above the bridge to be sampled when the wind was on the bow, thus minimizing interference from ship stack emissions. Contamination events were screened out using a real-time clean-sector sampling "baseline" flag and switch (Harvey et al., 2017), enabling the clean collection of integrated samples. Although the vessel exhaust was the primary contaminant, other potential sources included the work- boat and recirculation of polluted air around the ship, and longer-range terrestrial influences were also assessed. Measurements of black carbon using an aethalometer and $\mathrm{CO}_{2}$ by high-precision cavity ring-down laser spectroscopy (CRDS) provided two independent variables for detecting contamination events, and some VOCs, measured by proton transfer reaction mass spectrometer (PTR-MS; see Table 2), were also used as indicators of diesel combustion. The vessel was orientated into the wind as often as possible, which resulted in a high frequency $(\sim 75 \%)$ of baseline sector conditions during the SOAP voyage. Clean marine air periods were defined post-voyage, using the baseline wind sector (225$135^{\circ}$ relative to bow and wind speed greater than $3 \mathrm{~m} \mathrm{~s}^{-1}$ ), black carbon concentrations (less than $50 \mathrm{ng} \mathrm{m}^{-3}$ ) and back trajectories, and indicated minimal terrestrial impact (periods when the minimum number of hours over land in $72 \mathrm{~h}$ back trajectory is zero), with periods of workboat operations removed. An ensemble of Hybrid Single-Particle Lagrangian Integrated Trajectory (HYSPLIT) model back trajectories (Draxler and Rolph, 2013) was run for each hour of the voyage, and NAME back trajectories were calculated for every $3 \mathrm{~h}$ (Fig. 5; Jones et al., 2007). Figure 10 shows particle number and $\mathrm{CCN}$ concentrations compared to the number of hours the $72 \mathrm{~h}$ back trajectory spent over land cal- 


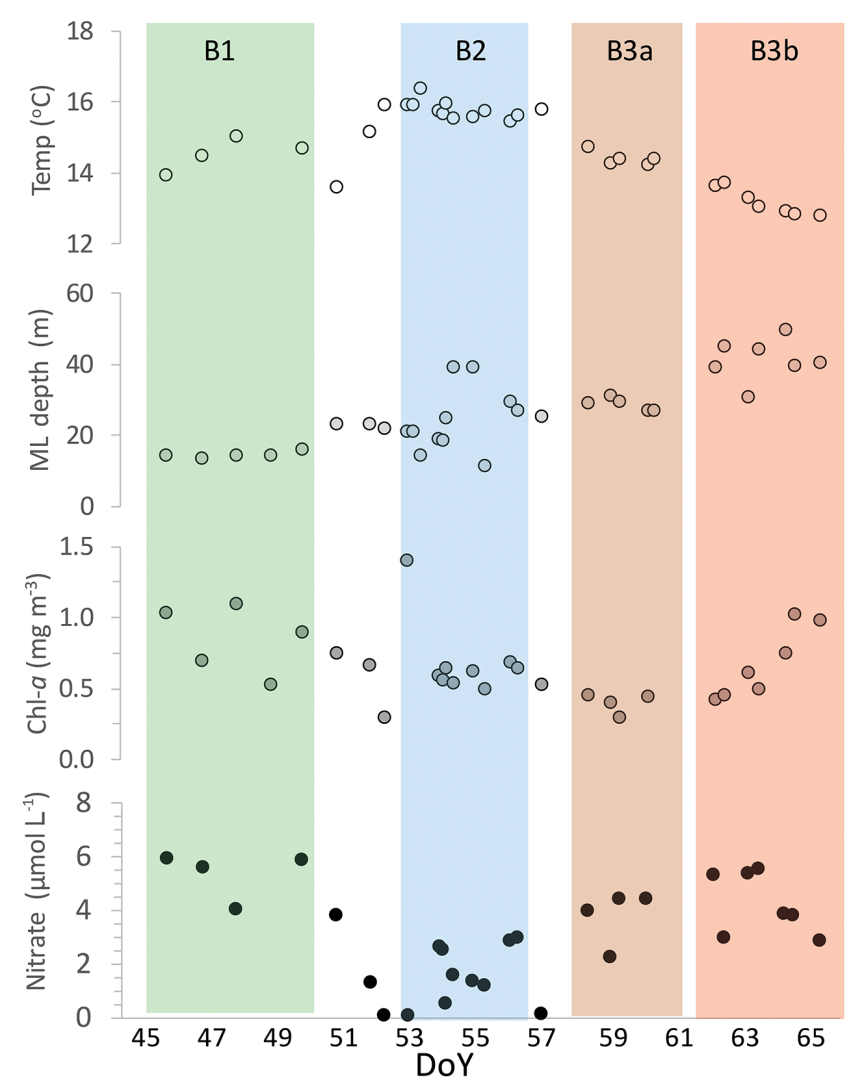

Figure 7. Surface water properties $(2-10 \mathrm{~m})$ recorded at each station during the SOAP voyage: temperature (Temp, $\left.{ }^{\circ} \mathrm{C}\right)$, mixed layer depth (ML depth, m), chlorophyll $a$ (Chl- $a, \mathrm{mg} \mathrm{m}^{-3}$ ) and nitrate concentration $\left(\mu \mathrm{mol} \mathrm{L}{ }^{-1}\right)$ plotted against day of year (DoY), with the occupation period for each bloom indicated by the vertical shaded bars and bloom labels at the top of the figure.

culated from HYSPLIT trajectories. Particle concentrations were generally higher during periods of terrestrial influence (see DoY 52 and 60; Fig. 10), with average particle number concentrations of $1122 \pm 1482 \mathrm{~cm}^{-3}$, double that observed for clean marine air. Ion beam analysis also revealed the presence of silicate and aluminium on ambient submicron filter samples, suggesting a terrestrial source and supporting the back-trajectory modeling of continental outflow.

During the initial occupation of B1 under light winds, the particulate matter $\left(\mathrm{PM}_{10}\right)$ total ion mass was $9.5 \mu \mathrm{g} \mathrm{m}{ }^{-3}$ compared to subsequent samples under higher winds in the range $20-50 \mu \mathrm{g} \mathrm{m}^{-3}$. The dominant components of the inorganic mass fraction were sea salt ions and $\mathrm{nssSO}_{4}$, although a measurable organic fraction was also present (see below). The $\mathrm{NaCl}$ mass in light winds during B1 was $6.6 \mu \mathrm{g} \mathrm{m}^{-3}$ with $>95 \%$ being $>3 \mu \mathrm{m}$ in diameter, relative to $32.5 \mu \mathrm{g} \mathrm{m}^{-3}$ under stronger winds during B3b. Although $72 \%$ was $>3 \mu \mathrm{m}$, the largest difference in mass occurred in the 1.5 to $3 \mu \mathrm{m}$ size range. In contrast, the mass of $\mathrm{nssSO}_{4}$ was predominantly submicron sized; $\mathrm{B} 1$ exhibited the largest $\mathrm{nssSO}_{4}$ mass at
$2.0 \mu \mathrm{g} \mathrm{m}^{-3}$ with $85 \%$ in sizes $<1 \mu \mathrm{m}$, whereas in $\mathrm{B} 3 \mathrm{~b}$, the $\mathrm{nssSO}_{4}$ mass was much lower at $0.6 \mu \mathrm{g} \mathrm{m}^{-3}$ with $76 \%$ with sizes $<1 \mu \mathrm{m}$. These results confirm the influence of both physical and biogeochemical processes on aerosol composition.

Voyage particle number concentrations during clean marine periods averaged $534 \pm 338 \mathrm{~cm}^{-3}$, with $\mathrm{CCN}$ concentrations of $178 \pm 87 \mathrm{~cm}^{-3}( \pm 1 \mathrm{sd})$ at $0.5 \%$ supersaturation and an average particle fraction activated into CCN of $0.4 \pm 0.2$. Bloom average particle number concentrations ranged from a minimum of $385 \pm 96 \mathrm{~cm}^{-3}$ in $\mathrm{B} 3 \mathrm{~b}$ to a maximum $830 \pm 255 \mathrm{~cm}^{-3}$ at the start of B2 (Fig. 10). B1 displayed the highest CCN activation ratio, of $0.5 \pm 0.2$, potentially due to the combination of low wind speeds, large biogeochemical signals and SMA fluxes. Comparison of the inorganic ion mass, determined from high-volume sampler filters, between the different blooms does not support the conclusion that the B1 activation ratio was higher simply because particles were larger. As the median particle diameters during clean marine periods were consistent between the three blooms, this suggests that particle composition, secondary organics or coagulation may have impacted $\mathrm{CCN}$ activation at B1. These findings are supported by preliminary results from an application of the ACCESSUKCA model (M. Woodhouse, personal communication, 2017), which simulated the additional impact of emissions of marine secondary organic carbon under the conditions determined during SOAP. In contrast, the average CCN activation ratio for $\mathrm{B} 3 \mathrm{a}$ was lower at $0.13 \pm 0.06$. Nucleation mode particles $(10$ and $15 \mathrm{~nm}$ ) were measured by ultrafine organic tandem differential mobility analyzer (UFO-TDMA; Vaattovaara et al., 2005) and Aitken mode particles (50 nm) by UFO-TDMA and a volatility and hygroscopicity tandem differential mobility analyzer (VH-TDMA; Johnson et al., 2004; Villani et al., 2008). This analysis typically identified a significant (up to $50 \%$ volume fraction) secondary organic component during sunny conditions in bloom regions, particularly during B1. The TDMA results provided further evidence for secondary organic aerosol processing of the dominant secondary nssSO ${ }_{4}$ mode during B1. Deliquescence measurements (VH-TDMA) indicate that the Aitken mode population is largely comprised of neutralized $\mathrm{nssSO}_{4}$, i.e., ammonium sulfate. Small and sporadic contributions to the Aitken mode from a nonhygroscopic component (number fraction up to 0.4 ) and a highly hygroscopic component (number fraction up to 0.3 ) were observed in addition to the secondary $\mathrm{nssSO}_{4}$ mode (number fraction of $0.6-1$ ). The water uptake and volatility of the sporadic highly hygroscopic mode indicates that this may be composed of PMA.

The in situ aerosol size, number and composition measurements in the MBL were complemented by in vitro chamber measurements of nascent SSA to determine the PMA organic volume fraction and water uptake properties. Nascent SSA filter samples were analyzed using Fourier transform infrared spectroscopy (FTIR) for organic functional groups (Russell 


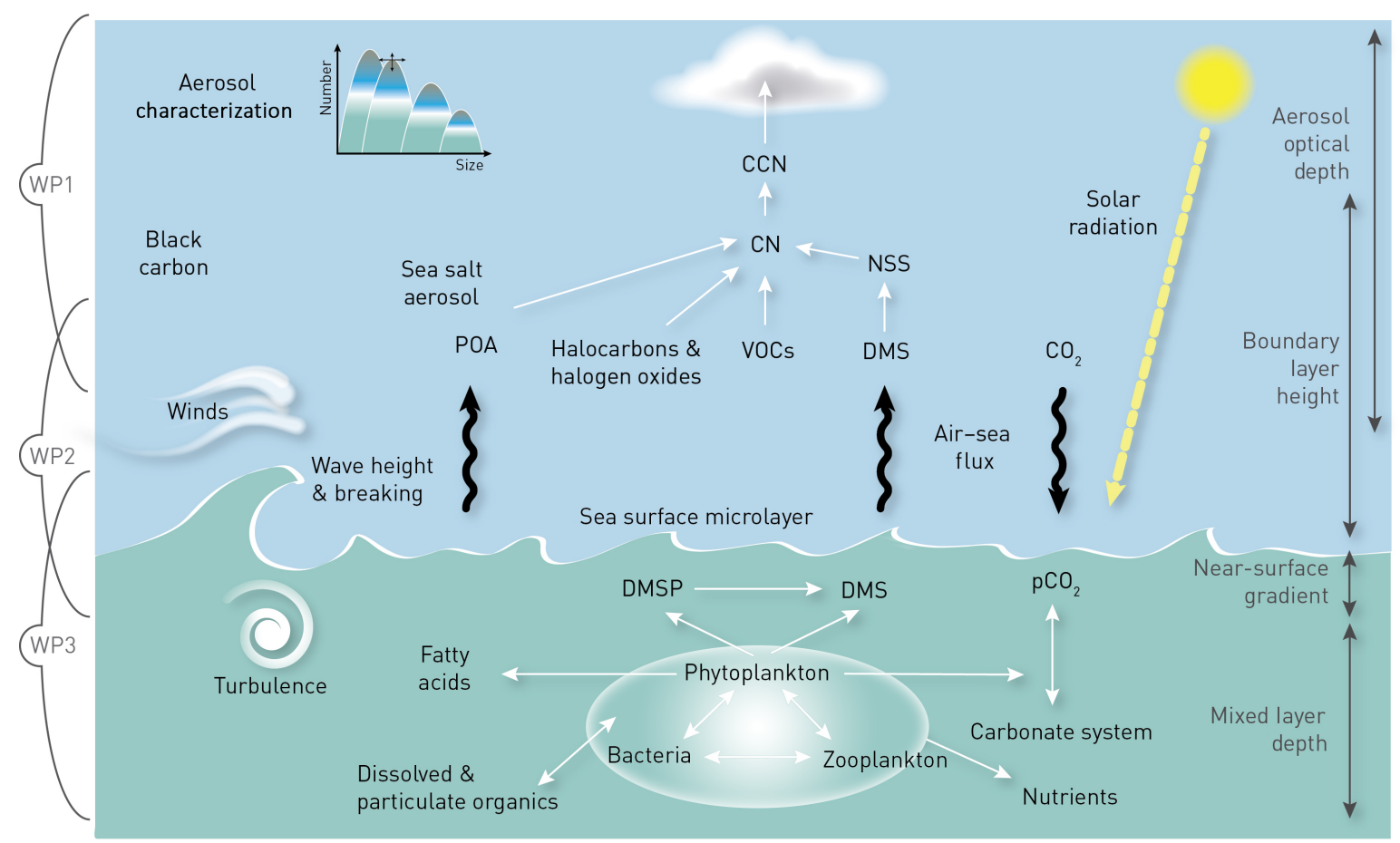

Figure 8. Conceptual figure of the parameters, processes and vertical range measured during SOAP, with the integrated work programmes (WP) indicated on the left of the figure. CN: condensation nuclei. NSS: non sea salt.

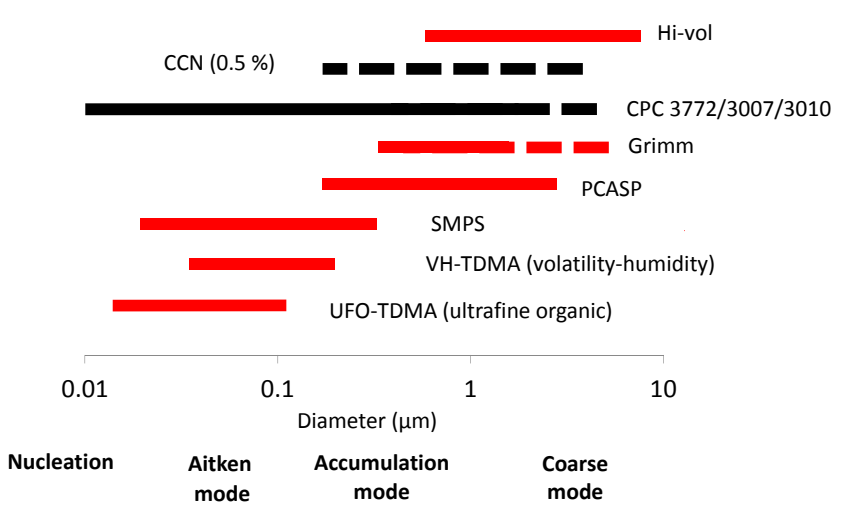

Figure 9. Aerosol characterization during SOAP, indicating size spectral (red) and total count (black) range for each instrument, relative to aerosol size and mode. Ambient RH measurement was used for RH correction of the PCASP, Hi Vol and SMPS, and diffusion driers (Silica Gel) were used on the inlet of the UFO-TDMA and VH-TDMA.

et al., 2011) and ion beam analysis for inorganic concentrations (Cohen et al., 2004). Measurements of the hygroscopic growth factor and the volatile fraction up to $450^{\circ} \mathrm{C}$ for 50 $150 \mathrm{~nm}$ particles using the VH-TDMA were compared with those of reference inorganic samples (e.g., sea salt, ammonium sulfate) to determine their organic volume fractions (Modini et al., 2010). Complementing the VH-TDMA, the UFO-TDMA provided further information on the organic content of particles of $50 \mathrm{~nm}$ and down to $10 \mathrm{~nm}$. The bubble chamber observations indicated that the PMA contained a substantial primary organic fraction. VH-TDMA results indicate that the Aitken mode PMA was primarily nonvolatile (78-93\%), with an average organic volume fraction of $51 \%$ (ranging from 39 to $68 \%$ ), and the UFO-TDMA results show an organic volume fraction (OVF) ranging from 35 to $45 \%$. These results are consistent with observations in the North Pacific and Atlantic, for which an Aitken mode volatile fraction of the order of $15 \%$ and OVF of $0.4-0.8$ have been observed (Quinn et al., 2014). FTIR analysis indicated that the POA aerosol in the chamber experiments was largely composed of hydroxyl functional groups, with minor contributions from alkanes, amines and carboxylic acid groups, consistent with previous observations (Russell et al., 2011).

Although DMS was a primary focus of measurements during SOAP, a wide variety of other VOCs that potentially contribute to secondary organic aerosol formation were also measured. Halogens and halogen oxides were measured using multi-axis differential optical absorption spectroscopy (Max-DOAS) and electron capture detector-gas chromatography (ECD-GC). Iodine has been identified as a potentially important precursor of nucleation in coastal regions (Sellegri et al., 2005), and SOAP provided an opportunity to relate the presence of halogen oxides to phytoplankton biomass and composition in the surface ocean and nucleation events in the MBL. A high-sensitivity PTR-MS carried out measurements continuously in $\mathrm{H}_{3} \mathrm{O}^{+}$mode in the range 

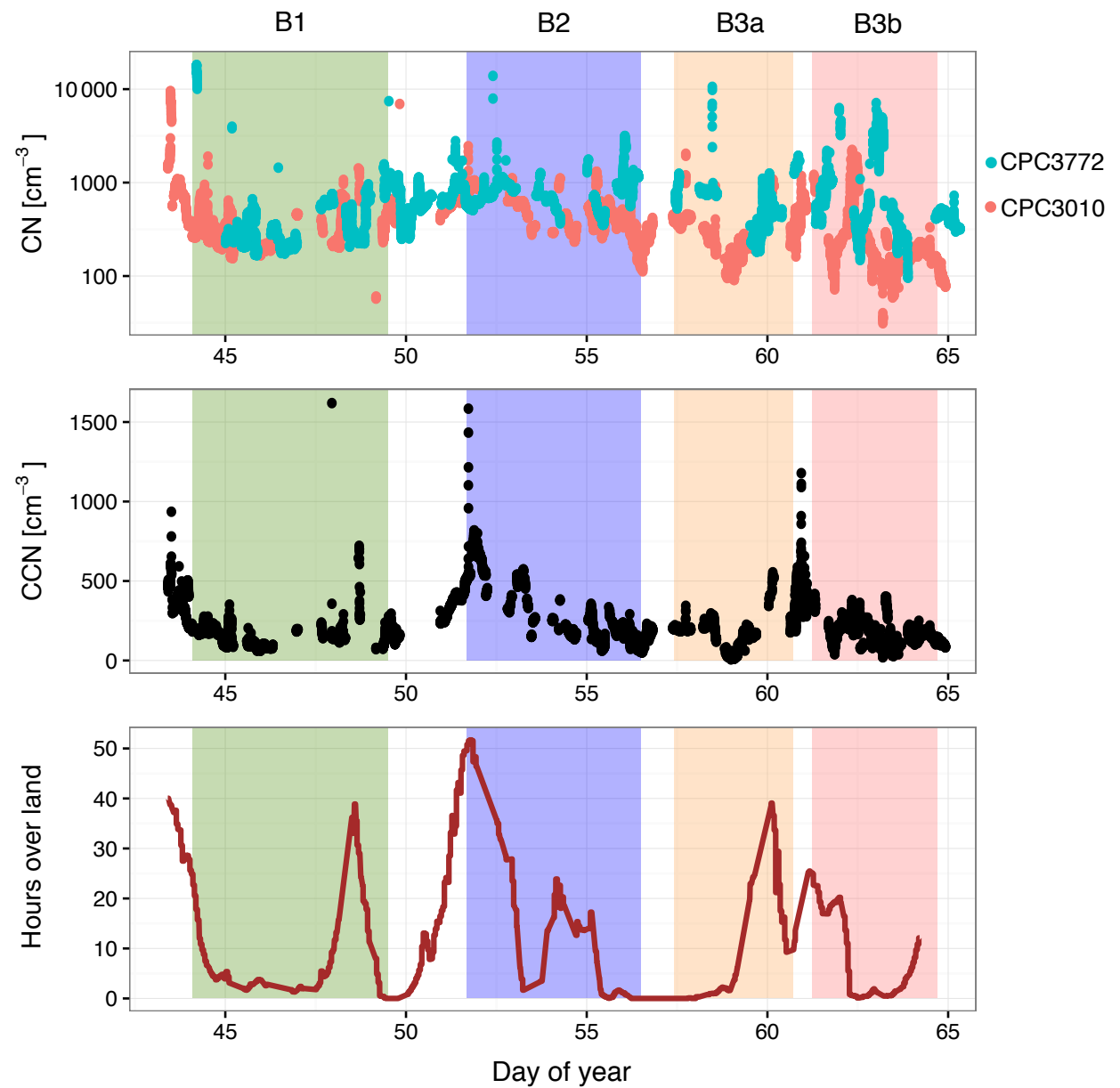

Figure 10. (a) Marine boundary layer $\mathrm{CN}$ concentrations $\left(\mathrm{cm}^{-3}\right.$; top; CPC3772 in blue, CPC3010 in red), (b) CCN concentrations (middle; $\mathrm{cm}^{-3}$ ) and (c) number of hours over land indicated by $72 \mathrm{~h}$ back trajectory (bottom; 27-member ensemble average). Bloom occupation periods are indicated by the vertical shaded bars and bloom labels at the top of the figure.

of $m / z 21-m / z 155$ throughout the voyage (Lawson et al., 2017). Aldehydes, ketones and dicarbonyls were measured using 2,4-dinitrophenylhydrazine (2,4-DNPH) cartridges and high-performance liquid chromatography (HPLC; Lawson et al., 2015), and a range of VOCs were sampled using adsorbent tubes and later analyzed via thermal desorptiongas chromatography-flame ionization detection-mass spectrometry (TD-GC-FID/MS). These measurements identified a positive relationship between DMS $(m / z 63)$, acetone $(\mathrm{m} / z 59)$ and methanethiol $(\mathrm{m} / \mathrm{z} 49)$, indicating common biological drivers (Lawson et al., 2017).

The first in situ measurements of aqueous phase SMA precursors dicarbonyls, glyoxal and methylglyoxal were obtained over the remote Southern Ocean during SOAP (Lawson et al., 2015). Parallel measurements of known dicarbonyl precursors, measured by PTR-MS, were used to calculate the expected yields of glyoxal and methyl glyoxal, which accounted for $<30 \%$ of observed mixing ratios indicating an unidentified source of dicarbonyls (Lawson et al., 2015). This was corroborated by inclusion of SOAP gly- oxal measurements obtained by Max-DOAS measurement in a global database, which concluded that the missing glyoxal source was an order of magnitude greater than identified sources (Mahajan et al., 2014). Surface mixing ratios of glyoxal converted to vertical columns, were significantly lower than average vertical column densities (VCDs) from satellite retrievals, possibly reflecting the difficulty of retrieving low glyoxal VCDs over the ocean or, alternatively, incorrect assumptions about the vertical distribution of glyoxal in the atmosphere (Lawson et al., 2015).

\subsection{Rates and controls of volatile and precursor emissions at the air-sea interface}

DMS measurements were made using three different instruments during SOAP (see Table 2); an atmospheric pressure ionization-chemical ionization mass spectrometer (APICIMS) continuously monitored DMS in both phases (Bell et al., 2015), a PTR-MS monitored DMSa (Lawson et al., 2017), and discrete water measurements were made us- 
ing a sulfur chemiluminescence detector gas chromatograph (SCD-GC; Walker et al., 2016). Intercomparison of sulfur measurements is not easily or routinely performed (Bell et al., 2012), particularly at sea. Seawater DMS measurements (CIMS and SCD-GC) compared well during SOAP (Walker et al., 2016), and the SCD-GC technique also compared well with traditional gas chromatography (with flame photometric detector) in an international intercalibration exercise (Swan et al., 2014). Intercomparison of the PTR-MS and SCD during SOAP involved analysis of two air samples and two diluted DMS gas standards with a concentration range of 158-354 ppt. The instruments showed very good agreement, with a mean difference of $5 \%$ and a maximum of $10 \%$.

Although the majority of DMS flux estimates to date have been derived by applying an independently determined transfer velocity $(k)$ to the measured DMS gradient at the ocean surface $(\triangle \mathrm{DMS})$, there has been a recent increase in direct micrometeorological measurements of DMS flux. Measurements at 10-30 min resolution show considerable variability in flux, which may reflect methodological artefacts or inherent variability in the distribution of DMS. SOAP provided a platform for comparing EC flux measurements of DMS using API-CIMS (Bell et al., 2015), with a gradient flux technique using a drogued catamaran within $1 \mathrm{~km}$ of the vessel (Smith et al., 2017). The gradient flux technique is less direct than EC but provides an alternative reference on a platform that is relatively free of shipboard airflow distortion. The EC system sampled from an intake on the ships bow, with flux instruments mounted on the foremast $12.6 \mathrm{~m}$ above sea level and the air pumped to a containerized laboratory on the foredeck. Additional meteorological measurements were obtained from a weather station above the bridge. Both sites are subject to airflow distortion which is azimuthally dependent (Popinet et al., 2004). The catamaran sampling framework, which consisted of four air intakes distributed vertically on a $5.3 \mathrm{~m}$ mast, sampled closer to the water surface where gas gradients are largest. Flux measurements were augmented by continuous near-surface measurement of physical parameters using a range of sensors attached to a spar buoy, with stratification determined by temperature sensors at $0.5 \mathrm{~m}$ intervals (Walker et al., 2016) and turbulence determined by a vector acoustic doppler velocimeter at $0.6 \mathrm{~m}$ depth. This permitted comparison of $k_{\mathrm{DMS}}$ estimates with near-surface upper-ocean turbulence at a distance from the vessel (Smith et al., 2017). Wave-breaking whitecap coverage was monitored using a Campbell Scientific 5-megapixel camera (cc5mpx) located on the starboard side of the vessel (Scanlon and Ward, 2016). This provided an indicator of bubble entrainment, which contributes to the differential transfer rate of DMS and $\mathrm{CO}_{2}$ due to their different solubilities (Blomquist et al., 2006; Bell et al., 2017).

Although SOAP primarily focussed on DMS fluxes, EC measurements of $\mathrm{CO}_{2}$ flux were an important adjunct measurement for providing insight into gas exchange mecha- nisms and controls and improving gas transfer algorithms for gases of differing solubilities. Four LI-COR infrared gas analyzers were used for eddy covariance flux measurements of $\mathrm{CO}_{2}$ during SOAP, following the initial trials on PreSOAP. Comparison of EC measurements with wet and dry incoming gas streams and an empirically based post-processing correction indicated that only gas stream drying produced robust $\mathrm{CO}_{2}$ flux and $k_{\mathrm{CO}_{2}}$ estimates (Landwehr et al., 2014). A detailed examination of ship motion and airflow distortion effects resulted in a significant reduction in the scatter in the $\mathrm{CO}_{2}$ eddy covariance data (Landwehr et al., 2017). The ECderived $k_{\mathrm{CO}_{2}}$ estimates provided a better correlation with a linear fit to the EC friction velocity than with the $10 \mathrm{~m}$ neutral wind speed $(u 10 \mathrm{~N})$ and showed good agreement with dual tracer-derived estimates from the SAGE experiment conducted in this region in March-April 2004 (Ho et al., 2006). Measurement of DMS and $\mathrm{CO}_{2}$ fluxes also provided further constraint of $k$ parameterizations based upon wind speed and the opportunity to assess the influence of bubbles on gas exchange at high wind speeds. DMS fluxes derived by EC and gradient flux techniques showed good agreement (Bell et al., 2015; Smith et al., 2017) and confirmed previous observations that gas transfer is a linear function of wind speed at low to intermediate winds (Blomquist et al., 2006; Yang et al., 2011). Despite winds reaching $20 \mathrm{~m} \mathrm{~s}^{-1}$ during the latter part of SOAP, insufficient data were obtained to draw conclusions regarding the reported deviation of $k_{\text {DMS }}$ under high winds (Bell et al., 2015). However, SOAP provided a novel estimate of the size of the EC flux footprint and the temporalspatial mismatch between DMSsw and shipboard measured fluxes, highlighting the importance of considering skew in flux estimates arising from nonlinear distribution of DMSsw (Bell et al., 2015).

A further objective of SOAP was a comparison of measured DMS fluxes with calculated estimates from the COAREG model (Fairall et al., 2011) based on $\triangle$ DMS, to assess potential discrepancies with modeled fluxes (Marandino et al., 2008; Walker et al., 2016). Potential factors examined here included air and water stability and the influence of the SSM. Despite the agreement between DMS flux estimates by the two micrometeorological techniques, there was significant departure from COAREG predictions (Fairall et al., 2011) on occasions, suggesting the influence of unidentified processes (Smith et al., 2017). One example was the suppressed DMS flux during a period of atmospheric stability and reversed heat flux during B2. Concurrent EC flux measurement for DMS and $\mathrm{CO}_{2}$ also provided an opportunity to assess other influences on $k$. The DMS flux data indicate that the $k_{\mathrm{DMS}}-$ wind-speed relationship was relatively insensitive to surface biogeochemistry or wave action during SOAP (Bell et al., 2015). In addition, SOAP data were used to parameterize whitecap coverage against wind speed and identify the fact that maturing waves may obscure and lead to underestimation of the variability of breaking waves (Scanlon and Ward, 2016). 


\subsection{Surface ocean biogeochemical influences on aerosols and volatiles}

Surface mapping of DMSsw and $p \mathrm{CO}_{2}$, using API-CIMS and IRGA, respectively (Bell et al., 2015), were critical to the SOAP voyage strategy and the aims of the two work packages discussed above. These measurements also provided insight into the covariance of DMS sources and $\mathrm{CO}_{2}$ sinks in surface waters and establish the importance of this region to global budgets. The New Zealand Coastal (NEWZ) province (Longhurst, 1998), which includes the frontal region (STF) studied during SOAP, is characterized in the global DMS climatology by year-round low DMS concentrations with a maximum $<2 \mathrm{nmol} \mathrm{L}^{-1}$ (Lana et al., 2011). This infers that this region has some of the lowest global DMSsw concentrations, in marked contrast to the adjacent South Subtropical Convergence (SSTC) province, which occupies the remainder of the $35-50^{\circ} \mathrm{S}$ latitude band and also accommodates the STF and is characterized by a mid-summer maximum of $10 \mathrm{nmol} \mathrm{L}^{-1}$ DMS. This discrepancy between the two regions likely reflects the low number of DMS observations for the NEWZ province in the climatology $(n=6$; Lana et al., 2011). Previous DMSsw measurements in subantarctic waters south of the Chatham Rise, and east of Tasmania in the SSTC biome (Archer et al., 2011; Griffiths et al., 1999), are consistent with this climatological estimate, whereas larger unpublished surveys have recorded elevated surface DMSsw during austral spring (October 2000), with a mean DMSsw of $4.5( \pm 6.8) \mathrm{nmol} \mathrm{L}^{-1}$ on the Chatham Rise (BOX voyage, M. Harvey et al., personal communication, 2017). Combining these measurements with data from the SOAP campaign (mean DMSsw: $6.6 \mathrm{nmol} \mathrm{L}^{-1}$, Bell et al., 2015) gives a weighted-mean DMSsw of $5.3 \mathrm{nmol} \mathrm{L}^{-1}$ ( $n=5300$, see Table 3), confirming that DMSsw in the NEWZ province is currently underestimated, and is in fact more typical of the SSTC province. Although the PreSOAP and SOAP sampling strategy of focussing on phytoplankton blooms may introduce bias towards higher DMSsw, the BOX voyage, which had broad spatial coverage of subtropical and subantarctic waters between 39.5 and $47^{\circ} \mathrm{S}$, gave a similar mean DMSsw to the weighted mean for all voyages. The elevated DMSsw was reflected in the EC flux measurements during SOAP, which recorded maximum and mean fluxes of 100 and $16.3 \mu \mathrm{mol} \mathrm{S} \mathrm{m}{ }^{-2} \mathrm{~d}^{-1}$, respectively, (Bell et al., 2015), which exceed the climatological mean of $>10 \mu \mathrm{mol} \mathrm{S} \mathrm{m}{ }^{2} \mathrm{~d}^{-1}$ for the SSTC region (Lana et al., 2011). In addition, the high MBL DMS concentrations of $1000 \mathrm{ppt}$ recorded during SOAP exceed DMSa at coastal stations on the New Zealand North Island in summer (Harvey et al., 1993; de Bruyn et al., 2002; Wylie and de Mora, 1996). Although seasonally constrained, the SOAP measurements provide evidence that regional DMS emissions are significant in this region of the southwest Pacific. The increased dataset of regional concentrations and flux will allow further refinement of global climatologies, such as the Global Surface Water DMS Database and the Surface Ocean $\mathrm{CO}_{2}$ Atlas (SOCAT).

The spatial variability of DMSsw was related to surface ocean biogeochemistry and bloom type by measurement of a suite of ancillary parameters in underway mode, including temperature and salinity, $\mathrm{Chl} a$, chromophoric dissolved organic matter (CDOM), $\beta_{660}$ backscatter, dissolved oxygen and $p \mathrm{CO}_{2}$ (see Tables 1 and 2). The vertical variability of DMSsw and the dissolved and particulate pools of its precursor DMSP were quantified in the surface mixed layer at stations within each bloom and related to plankton biomass and community composition, nutrient and organic composition, and physical drivers (see Supplement Table S2). Process studies of DMSP cycling included deck incubations examining the bacterially mediated pathways of DMSP cleavage and demethylation in relation to different bloom dynamics (Lizotte et al., 2017). DMSP concentrations were relatively high, reaching a maximum of $160 \mathrm{nmol} \mathrm{L}^{-1}$, and showed significant correlation with phytoplankton biomass during SOAP. However, the yield of DMS from the bacterial conversion of dissolved DMSP was variable with no spatial trend, although a correlation with leucine incorporation indicates that DMSP was an important carbon source for bacteria. Overall, gross DMS production by bacteria in deck incubations of near-surface water was relatively low, at $<6 \mathrm{nmol} \mathrm{L}^{-1} \mathrm{~d}^{-1}$, inferring that phytoplankton-mediated conversion of DMSP was likely a significant near-surface source of DMS (Lizotte et al., 2017).

The SSM is a potentially important interface controlling MBL and aerosol composition, across which material exchanges between atmosphere and ocean. Physical and biogeochemical processes within this thin layer have the potential to alter transfer via factors, such as the concentration of organic material and enhanced biological and photochemical processing. Near-surface $\mathrm{CO}_{2}$ gradients have been observed (Calleja et al., 2005), and several studies report DMS enrichment in the SSM (see summary in Walker et al., 2016). If DMS consumption or production in the SSM is significant, this represents a potential source of discrepancy in comparison of measured fluxes with that calculated by the COAREG model (see above). The biogeochemistry of the SSM and the upper $1.6 \mathrm{~m}$ surface water were characterized at 10 stations during SOAP at distance from the research vessel to determine the spatial variability in composition within, and between, different phytoplankton blooms (Walker et al., 2016). Near-surface DMS gradients were generally negligible, except during B1 where low wind speed, near-surface stratification and high dinoflagellate abundance may have enhanced DMS in the SSM relative to subsurface waters. The observed DMS enrichment factors in the SSM during B1, ranging from 1.4 to 5.3, are some of the highest reported to date. The anomaly between measured DMS fluxes and COAREG estimated was also greatest during B1, inferring that DMS emissions, and associated $k$-wind-speed parameterizations, may be sensitive to DMS production in the SSM under certain 
Table 3. DMS data for the SW Pacific region east of New Zealand. SD: standard deviation; $n$ : number of measurements; FPD-GC: flame photometric detector - gas chromatograph; PFPD - pulsed flame photometric detector - gas chromatograph; MIMS - membrane inlet mass spectrometer; miniCIMS - atmospheric pressure chemical ionization mass spectrometer; SCD - sulfur chemiluminescent detector; Climatol. - climatology; n/a - not available.

\begin{tabular}{llllrrrrr}
\hline Voyage & Date & Latitude & Longitude & $\begin{array}{l}\text { Mean DMS } \\
(\mathrm{nmol} \mathrm{L}-1)\end{array}$ & SD & $n$ & Method & Reference \\
\hline BOX & October 2000 & $39.5-47^{\circ} \mathrm{S}$ & $170^{\circ} \mathrm{E}-179^{\circ} \mathrm{E}$ & 4.55 & 6.8 & 482 & FPD-GC & this paper \\
& November 2005 & $49-50^{\circ} \mathrm{S}$ & $175^{\circ} \mathrm{E}$ & 1.75 & - & 2 & FPD-GC & Kiene et al. (2007) \\
SAGE & April 2006 & $41-46.6^{\circ} \mathrm{S}$ & $172.5^{\circ} \mathrm{E}-178.5^{\circ} \mathrm{E}$ & 1.06 & 0.9 & 6 & PFPD & Archer et al. (2011) \\
PreSOAP & February 2011 & $42.5-44^{\circ} \mathrm{S}$ & $174^{\circ} \mathrm{E}-178^{\circ} \mathrm{W}$ & 2.2 & 2.0 & 736 & MIMS & this paper \\
SOAP & March-April 2012 & $41.7-46.5^{\circ} \mathrm{S}$ & $172^{\circ} \mathrm{E}-179^{\circ} \mathrm{W}$ & 6.36 & 4.4 & 4132 & miniCIMS & Bell et al. (2015) \\
SOAP & March-April 2012 & $41.7-46.5^{\circ} \mathrm{S}$ & $172^{\circ} \mathrm{E}-179^{\circ} \mathrm{W}$ & 11.5 & 9.2 & 22 & $\mathrm{SCD}$ & Walker et al. (2016) \\
\hline SW Pacific & Weighted mean & $39.5-50^{\circ} \mathrm{S}$ & $170^{\circ} \mathrm{E}-179^{\circ} \mathrm{W}$ & 5.6 & 5380 & & this paper \\
NEWZ & & $35-55^{\circ} \mathrm{S}$ & $170^{\circ} \mathrm{E}-170^{\circ} \mathrm{W}$ & $0.05-2.0$ & 6 & Climatol. & Lana et al. (2011) \\
SSTC & & $35-50^{\circ} \mathrm{S}$ & $170^{\circ} \mathrm{E}-170^{\circ} \mathrm{W}$ & $0.05-10$ & & n/a & Climatol. & Lana et al. (2011) \\
\hline
\end{tabular}

conditions. However, the observations also raise questions as to how such significant DMS enrichment is maintained in the SSM, as high DMS production would be required to balance loss processes (Walker et al., 2016).

\section{Conclusions}

The SOAP voyage has identified new questions in important areas of research relating to the Surface Ocean - Lower Atmosphere Study project (SOLAS), including the influence of the SSM on DMS emissions, implications for secondary aerosol formation and unidentified sources of organic aerosol precursors, all of which are potentially influenced by photochemistry in the surface ocean and MBL (Lawson et al., 2015). It has also addressed confounding technical challenges including small-scale heterogeneity in surface waters, clean-air baseline sampling, and discrepancies between existing techniques and models. An overarching aim of the SOAP campaign was to assess potential relationships between surface water biogeochemistry and corresponding or related species in the MBL and to identify the factors influencing aerosol precursors and their potential as analogues. $\mathrm{Chl} a$ is an indicator of phytoplankton biomass that is readily retrievable by satellite and consequently has been investigated as a potential proxy for DMSsw (Lana et al., 2011). The SOAP voyage provided a platform to validate this observation, particularly as it took place in the $40-60^{\circ} \mathrm{S}$ latitude band, which exhibits the most significant regional correlation between Chl $a$ and DMSsw (Vallina et al., 2006). Overall there was a weak, but significant, correlation $(r=0.12$, $p<0.005)$ between Chl $a$ and DMSsw in the underway surface data during SOAP (Bell et al., 2015) but also significant variability in the slope and the sign of this relationship between the different blooms. Correlations were also apparent between Chl $a$ and DMSP (Lizotte et al., 2017) and Chl $a$ and DMSa, but there was no relationship between Chl $a$ and
DMS flux, as expected, due to the short timescales and flux footprint identified by Bell et al. (2015). Correlations have been reported previously for Chl $a$ with CCN (Meskhidze and Nenes, 2006) and aerosol organic enrichment (Gantt et al., 2011), although other assessments have shown variable results (Russell et al., 2010; Rinaldi et al., 2013). The measurement of PMA and SMA composition and number coincident with multispecies characterization of the MBL and surface water composition during SOAP has provided a broad database with which to assess and develop these relationships for potential application in remote sensing and earth system models. The first step towards this is the inclusion of SOAP aerosol and tropospheric data in the global ACCESSUKCA model (Woodhouse et al., 2015), which uses the GLOMAP (GLObal Model of Aerosol Processes model)mode aerosol scheme (Mann et al., 2010, 2012), which shows very good agreement with observed distributions of condensation nuclei (M. Woodhouse et al., personal communication, 2017)

Data availability. The underway DMSsw can be downloaded at http://saga.pmel.noaa.gov/dms/select.php. The remaining data are available by request email to cliff.law@niwa.co.nz.

\section{The Supplement related to this article is available online at https://doi.org/10.5194/acp-17-13645-2017- supplement.}

Author contributions. The SOAP campaign was led and coordinated by CSL, MJS and MJH. All authors developed the analytical methods and instruments used during the SOAP campaign, and CSL, MJS, MJH, TGB, LTC, FCE, SJL, ML, AM, JM, KAS, $\mathrm{PV}$ and $\mathrm{CFW}$ made measurements during the SOAP voyage. All authors were involved in analysis and interpretation of data. CSL led the manuscript production, with contributions from MJS, MJH, TGB, LTC, SJL, ML, ZR, KA, ES, PV and CFW. 
Competing interests. The authors declare that they have no conflict of interest.

Special issue statement. This article is part of the special issue "Surface Ocean Aerosol Production (SOAP) (ACP/OS inter-journal SI)". It is not associated with a conference.

Acknowledgements. We acknowledge the invaluable assistance of the captain, officers and crew of the R/V Tangaroa. We thank Kim Currie, Steve George, Matt Walkington, Mark Gall, Marc Mallet, Greg Olsen, Gus Olivares and Nick Talbot for collection and analysis of samples; Christa Marandino, Warren DeBruyn and Cyril McCormick for assistance with API-CIMS measurements; Sebastian Landwehr, Scott Miller and Brian Ward for $\mathrm{CO}_{2}$ flux measurements; Paul Johnson, Karin Kreher and Neil Harris for halocarbon and VOC measurements; Jason Ward for assistance with CCN measurement; Gordon Brailsford for Picarro setup; Paul Selleck and Min Cheng for analysis of VOC samples; Sarah Connors for the back-trajectory suite using the UK Met Office NAME model; and Matt Woodhouse for analysis of SOAP data using the global ACCESS-UKCA model. We also acknowledge Maurice Levasseur and Melita Keywood for their comments and support of the microbial DMSP cycling and VOC measurements, respectively. This research was supported by funding from NIWA's Climate and Atmosphere Research Programme 3 - Role of the oceans (2015/16 SCI) and a Postdoctoral Fellowship (CO1X0911) for Carolyn F. Walker from the New Zealand Ministry for Business, Innovation and Employment (MBIE). Flux measurements were supported by an NSF Atmospheric Chemistry Program (grant nos. 08568, 0851472, 0851407 and 1143709), and VOC and CCN measurements were supported by CSIRO's Capability Development Fund. Petri Vaattovaara's participation was supported by EU COST action 735, the Academy of Finland, through the Centre of Excellence and via a Finnish Academy visiting grant, no. 136841. Sarah J. Lawson's participation was supported by Science Foundation Ireland as part of the US-Ireland R\&D Partnership Programme under grant number 08/US/I1455 and an SFI Short-term Travel Fellowship under grant 09/US/I1758-STTF-11. We thank the Natural Sciences and Engineering Research Council of Canada (NSERC) for supporting the microbial DMSP cycling research.

Edited by: Mario Hoppema

Reviewed by: Rafel Simó and two anonymous referees

\section{References}

Allen, A. G., Dick, A. L., and Davison, B. M.: Sources of atmospheric methanesulphonate, non-sea-salt sulphate, nitrate and related species over the temperate South Pacific, Atmos. Environ., 31, 191-205, https://doi.org/10.1016/1352-2310(96)00194$\mathrm{x}, 1997$.

Almeida, J., Schobesberger, S., Kürten, A., Ortega, I. K., Kupiainen-Maatta, O., Praplan, A. P., Adamov, A., Amorim, A., Bianchi, F., Breitenlechner, M., David, A., Dommen, J., Donahue, N. M., Downard, A., Dunne, E., Duplissy, J., Ehrhart, S., Flagan, R. C., Franchin, A., Guida, R., Hakala, J., Hansel, A., Heinritzi, M., Henschel, H., Jokinen, T., Junninen, H., Kajos, M., Kangasluoma, J., Keskinen, H., Kupc, A., Kurtén, T., Kvashin, A. N., Laaksonen, A., Lehtipalo, K., Leiminger, M., Leppa, J., Loukonen, V., Makhmutov, V., Mathot, S., McGrath, M. J., Nieminen, T., Olenius, T., Onnela, A., Petäjä, T., Riccobono, F., Riipinen, I., Rissanen, M., Rondo, L., Ruuskanen, T., Santos, F. D., Sarnela, N., Schallhart, S., Schnitzhofer, R., Seinfeld, J. H., Simon, M., Sipilä, M., Stozhkov, Y., Stratmann, F., Tomé, A., Trostl, J., Tsagkogeorgas, G., Vaattovaara, P., Viisanen, Y., Virtanen, A., Vrtala, A., Wagner, P. E., Weingartner, E., Wex, H., Williamson, C., Wimmer, D., Ye, P., Yli-Juuti, T., Carslaw, K. S., Kulmala, M., Curtius, J., Baltensperger, U., Worsnop, D. R., Vehkamaki, H., and Kirkby, J.: Molecular understanding of sulphuric acid-amine particle nucleation in the atmosphere, Nature, 502, 359-363, https://doi.org/10.1038/nature12663, 2013.

Andreae, M. O. and Rosenfeld, D.: Aerosol-cloudprecipitation interactions. Part 1 . The nature and sources of cloud-active aerosols, Earth-Sci. Rev., 89, 13-41, https://doi.org/10.1016/j.earscirev.2008.03.001, 2008.

Archer, S. D., Safi, K., Hall, A., Cummings, D. G., and Harvey, M.: Grazing suppression of dimethylsulphoniopropionate (DMSP) accumulation in iron-fertilised, sub-Antarctic waters, Deep-Sea Res. Pt II, 58, 839-850, https://doi.org/10.1016/j.dsr2.2010.10.022, 2011.

Ayers, G. P., Ivey, J. P., and Gillett, R. W.: Coherence between seasonal cycles of dimethylsulfide, methanesulfonate, and sulfate in Marine Air, Nature, 349, 404-406, 1991.

Balch, W. M., Drapeau, D. T., Bowler, B. C., Lyczskowski, E., Booth, E. S., and Alley, D.: The contribution of coccolithophores to the optical and inorganic carbon budgets during the Southern Ocean Gas Exchange Experiment: New evidence in support of the "Great Calcite Belt" hypothesis, J. Geophys. Res.-Oceans, 116, C00F06, https://doi.org/10.1029/2011jc006941, 2011.

Bell, T. G., Malin, G., Lee, G. A., Stefels, J., Archer, S., Steinke, M., and Matrai, P.: Global oceanic DMS data inter-comparability, Biogeochem., 110, 147-161, https://doi.org/10.1007/s10533011-9662-3, 2012.

Bell, T. G., De Bruyn, W., Marandino, C. A., Miller, S. D., Law, C. S., Smith, M. J., and Saltzman, E. S.: Dimethylsulfide gas transfer coefficients from algal blooms in the Southern Ocean, Atmos. Chem. Phys., 15, 1783-1794, https://doi.org/10.5194/acp15-1783-2015, 2015.

Bell, T. G., Landwehr, S., Miller, S. D., de Bruyn, W. J., Callaghan, A. H., Scanlon, B., Ward, B., Yang, M., and Saltzman, E. S.: Estimation of bubble-mediated air-sea gas exchange from concurrent DMS and $\mathrm{CO}_{2}$ transfer velocities at intermediate-high wind speeds, Atmos. Chem. Phys., 17, 90199033, https://doi.org/10.5194/acp-17-9019-2017, 2017. 
Blake, N. J., Blake, D. R., Wingenter, O. W., Sive, B. C., Kang, C. H., Thornton, D. C., Bandy, A. R., Atlas, E., Flocke, F., Harris, J. M., and Rowland, F. S.: Aircraft measurements of the latitudinal, vertical, and seasonal variations of NMHCs, methyl nitrate, methyl halides, and DMS during the First Aerosol Characterization Experiment (ACE 1), J. Geophys. Res.-Atmos., 104, $21803-$ 21817, https://doi.org/10.1029/1999jd900238, 1999.

Blomquist, B. W., Fairall, C. W., Huebert, B. J., Kieber, D. J., and Westby, G. R.: DMS sea-air transfer velocity: Direct measurements by eddy covariance and parameterization based on the NOAA/COARE gas transfer model, Geophys. Res. Lett., 33, L07601, https://doi.org/10.1029/2006GL025735, 2006.

Blot, R., Clarke, A. D., Freitag, S., Kapustin, V., Howell, S. G., Jensen, J. B., Shank, L. M., McNaughton, C. S., and Brekhovskikh, V.: Ultrafine sea spray aerosol over the southeastern Pacific: open-ocean contributions to marine boundary layer CCN, Atmos. Chem. Phys., 13, 7263-7278, https://doi.org/10.5194/acp-13-7263-2013, 2013.

Boers, R., Jensen, J. B., Krummel, P. B., and Gerber, H.: Microphysical and radiative structure of wintertime marine stratocumulus clouds over the Southern Ocean, Q. J. Roy. Meteor. Soc., 122, 1307-1339, 1996.

Boers, R., Jensen, J. B., and Krummel, P. B.: Microphysical and shortwave radiative structure of stratocumulus clouds over the Southern Ocean: summer results and seasonal differences, Q. J. Roy. Meteor. Soc., 124, 151-168, 1998.

Boyd, P., LaRoche, J., Gall, M., Frew, R., and McKay, R. M. L.: Role of iron, light, and silicate in controlling algal biomass in subantarctic waters SE of New Zealand, J. Geophys. Res.-Oceans, 104, 13395-13408, https://doi.org/10.1029/1999jc900009, 1999.

Boyd, P. W., McTainsh, G., Sherlock, V., Richardson, K., Nichol, S., Ellwood, M., and Frew, R.: Episodic enhancement of phytoplankton stocks in New Zealand subantarctic waters: Contribution of atmospheric and oceanic iron supply, Global Biogeochem. Cy., 18, GB1029, https://doi.org/10.1029/2002GB002020, 2004.

Bradford-Grieve, J. M., Boyd, P. W., Chang, F. H., Chiswell, S., Hadfield, M., Hall, J. A., James, M. R., Nodder, S. D., and Shushkina, E. A.: Pelagic ecosystem structure and functioning in the Subtropical Front region east of New Zealand in austral winter and spring 1993, J. Plankton Res., 21, 405-428, https://doi.org/10.1093/plankt/21.3.405, 1999.

Cainey, J. and Harvey, M.: Dimethylsulfide, a limited contributor to new particle formation in the clean marine boundary layer, Geophys. Res. Lett., 29, 32-1-32-4, https://doi.org/10.1029/2001GL014439, 2002.

Calleja, M. L., Duarte, C. M., Navarro, N., and Agustí, S.: Control of air-sea $\mathrm{CO}_{2}$ disequilibria in the subtropical NE Atlantic by planktonic metabolism under the ocean skin, Geophys. Res. Lett., 32, L08606, https://doi.org/10.1029/2004GL022120, 2005.

Calleja, M. L., Duarte, C. M., Alvarez, M., Vaquer-Sunyer, R., Agusti, S., and Herndl, G. J.: Prevalence of strong vertical $\mathrm{CO}_{2}$ and O-2 variability in the top meters of the ocean, Global Biogeochem. Cy., 27, 941-949, https://doi.org/10.1002/gbc.20081, 2013.

Carslaw, K. S., Boucher, O., Spracklen, D. V., Mann, G. W., Rae, J. G. L., Woodward, S., and Kulmala, M.: A review of natural aerosol interactions and feedbacks within the Earth system, At- mos. Chem. Phys., 10, 1701-1737, https://doi.org/10.5194/acp10-1701-2010, 2010.

Carslaw, K. S., Lee, L. A., Reddington, C. L., Pringle, K. J., Rap, A., Forster, P. M., Mann, G. W., Spracklen, D. V., Woodhouse, M. T., Regayre, L. A., and Pierce, J. R.: Large contribution of natural aerosols to uncertainty in indirect forcing, Nature, 503 , 66-71, 2013.

Chang, F. H. and Gall, M.: Phytoplankton assemblages and photosynthetic pigments during winter and spring in the Subtropical Convergence region near New Zealand, New Zeal. J. Mar. Fresh., 32, 515-530, 1998.

Chang, R. Y. W., Sjostedt, S. J., Pierce, J. R., Papakyriakou, T. N., Scarratt, M. G., Michaud, S., Levasseur, M., Leaitch, W. R., and Abbatt, J. P.: Relating atmospheric and oceanic DMS levels to particle nucleation events in the Canadian Arctic, J. Geophys. Res.-Atmos., 116, D00S03, https://doi.org/10.1029/2011JD015926, 2011.

Charlson, R. J., Lovelock, J. E., Andreae, M. O., and Warren, S. G.: Oceanic phytoplankton, atmospheric sulfur, cloud albedo and climate, Nature, 326, 655-661, https://doi.org/10.1038/326655A0, 1987.

Chiswell, S. M., Bradford-Grieve, J., Hadfield, M. G., and Kennan, S. C.: Climatology of surface chlorophyll a, autumn-winter and spring blooms in the southwest Pacific Ocean, J. Geophys. Re.Oceans, 118, 1003-1018, https://doi.org/10.1002/jgrc.20088, 2013.

Ciuraru, R., Fine, L., Pinxteren, M. V., D’Anna, B., Herrmann, H., and George, C.: Unravelling new processes at interfaces: Photochemical isoprene production at the sea surface, Environ. Sci. Technol., 49, 13199-13205, 2015.

Clarke, A. D., Freitag, S., Simpson, R. M. C., Hudson, J. G., Howell, S. G., Brekhovskikh, V. L., Campos, T., Kapustin, V. N., and Zhou, J.: Free troposphere as a major source of $\mathrm{CCN}$ for the equatorial pacific boundary layer: long-range transport and teleconnections, Atmos. Chem. Phys., 13, 7511-7529, https://doi.org/10.5194/acp-13-7511-2013, 2013.

Cohen, D. D., Stelcer, E., Hawas, O., and Garton, D.: IBA methods for characterisation of fine particulate atmospheric pollution: a local, regional and global research problem, The 13th International Conference on Particle Induced X-ray Emission (PIXE 2013), 219-220, 145-152, 2004.

Cravigan, L. T., Ristovski, Z., Modini, R. L., Keywood, M. D., and Gras, J. L.: Observation of sea-salt fraction in sub-100 nm diameter particles at Cape Grim, J. Geophys. Res.-Atmos., 5, 2014JD022601, https://doi.org/10.1002/2014JD022601, 2015.

de Bruyn, W. J., Harvey, M., Cainey, J. M., and Saltzman, E. S.: DMS and $\mathrm{SO}_{2}$ at Baring Head, New Zealand: Implications for the yield of $\mathrm{SO}_{2}$ from DMS, J. Atmos. Chem., 41, 189-209, https://doi.org/10.1023/a:1014252106572, 2002.

Decesari, S., Finessi, E., Rinaldi, M., Paglione, M., Fuzzi, S., Stephanou, E. G., Tziaras, T., Spyros, A., Ceburnis, D., O'Dowd, C., and Dall'Osto, M.: Primary and secondary marine organic aerosols over the North Atlantic Ocean during the MAP experiment, J. Geophys. Res.-Atmos., 116, D22210, https://doi.org/10.1029/2011JD016204, 2011.

de Leeuw, G., Guieu, C., Arneth, A., Bellouin, N., Bopp, L., Boyd, P. W., van der Gon, H. A. C. D., Desboeufs, K. V., Dulac, F., Facchini, M. C., Gantt, B., Langmann, B., Mahowald, N. M., Maranön, E., O’Dowd, C., Olgun, N., Pulido-Villena, E., Rinaldi, 
M., Stephanou, E. G., and Wagener, T.: Ocean-Atmosphere Interactions of Particles, edited by: Liss, P. S. and Johnson, M. T., Ocean-Atmosphere Interactions of Gases and Particles, Springer Earth System Sciences, 171-246, https://doi.org/10.1007/978-3642-25643-1_4, 2014.

Delizo, L., Smith, W. O., and Hall, J.: Taxonomic composition and growth rates of phytoplankton assemblages at the Subtropical Convergence east of New Zealand, J. Plankton Res., 29, 655670, https://doi.org/10.1093/plankt/fbm047, 2007.

Draxler, R. R. and Rolph, G. D. (Eds.): HYSPLIT(HYbrid SinglePArticle Lagrangian Intergrated Trajectory) Model, NOAA Air Resources Laboratory, College Park, MD, available at: http://www.arl.noaa.gov/HYSPLIT.php, last access: 1 September 2013.

Facchini, M. C., Rinaldi, M., Decesari, S., Carbone, C., Finessi, E., Mircea, M., Fuzzi, S., Ceburnis, D., Flanagan, R., Nilsson, E. D., de Leeuw, G., Martino, M., Woeltjen, J., and O'Dowd, C. D.: Primary submicron marine aerosol dominated by insoluble organic colloids and aggregates, Geophys. Res. Lett., 35, L17814, https://doi.org/10.1029/2008GL034210, 2008.

Fairall, C. W., Bradley, E. F., Hare, J. E., Grachev, A. A., and Edson, J. B.: Bulk parameterization of air-sea fluxes: Updates and verification for the COARE algorithm, J. Climate, 16, 571-591, 2003.

Fairall, C. W., Yang, M. X., Bariteau, L., Edson, J. B., Helmig, D., McGillis, W., Pezoa, S., Hare, J. E., Huebert, B., and Blomquist, B.: Implementation of the Coupled OceanAtmosphere Response Experiment flux algorithm with $\mathrm{CO}_{2}$, dimethyl sulfide, and O-3, J. Geophys. Res.-Oceans, 116, C00F09, https://doi.org/10.1029/2010jc006884, 2011.

Gantt, B. and Meskhidze, N.: The physical and chemical characteristics of marine primary organic aerosol: a review, Atmos. Chem. Phys., 13, 3979-3996, https://doi.org/10.5194/acp13-3979-2013, 2013.

Gantt, B., Meskhidze, N., Facchini, M. C., Rinaldi, M., Ceburnis, D., and O'Dowd, C. D.: Wind speed dependent size-resolved parameterization for the organic mass fraction of sea spray aerosol, Atmos. Chem. Phys., 11, 8777-8790, https://doi.org/10.5194/acp-11-8777-2011, 2011.

Gondwe, M., Krol, M., Gieskes, W., Klaassen, W., and De Baar, H.: The contribution of ocean-leaving DMS to the global atmospheric burdens of DMS, MSA, $\mathrm{SO}_{2}$, and NSS SO4-, Global Biogeochem. Cy., 17, 1056, https://doi.org/10.1029/2002GB001937, 2003.

Griffiths, F. B., Bates, T. S., Quinn, P. K., Clementson, L. A., and Parslow, J. S.: Oceanographic context of the First Aerosol Characterization Experiment (ACE 1): A physical, chemical, and biological overview, J. Geophys. Res.-Atmos., 104, 21649-21671, https://doi.org/10.1029/1999jd900386, 1999.

Harvey, M. J., Wylie, D. J., Martin, R. J., Clarkson, T. S., and de Mora, S. J.: Dimethylsulphide measurements at Baring Head, New Zealand, in: Dimethylsulphide, Oceans, Atmosphere and Climate, edited by: Restelli, G., and Angeletti, G., Kluwer Academic, Dordrecht, 143-151, 1993.

Harvey, M. J., Law, C. S., Smith, M. J., Hall, J. A., Abraham, E. R., Stevens, C. L., Hadfield, M. G., Ho, D. T., Ward, B., Archer, S. D., Cainey, J. M., Currie, K. I., Devries, D., Ellwood, M. J., Hill, P., Jones, G. B., Katz, D., Kuparinen, J., Macaskill, B., Main, W., Marriner, A., McGregor, J., McNeil, C., Min- nett, P. J., Nodder, S. D., Peloquin, J., Pickmere, S., Pinkerton, M. H., Safi, K. A., Thompson, R., Walkington, M., Wright, S. W., and Ziolkowski, L. A.: The SOLAS air-sea gas exchange experiment (SAGE) 2004, Deep Sea Res. Pt. II, 58, 753-763, https://doi.org/10.1016/j.dsr2.2010.10.015, 2011.

Harvey, M. J., McGregor, J. A., Lawson, S. J., Cravigan, L., Talbot, N., Olivares, G., Conners, S., and Woodhouse, M.: Aerosol and tracer measurement at sea - defining the baseline, Atmos. Chem. Phys. Dicuss., in preparation, 2017.

Ho, D. T., Law, C. S., Smith, M. J., Schlosser, P., Harvey, M., and Hill, P.: Measurements of air-sea gas exchange at high wind speeds in the Southern Ocean: Implications for global parameterizations, Geophys. Res. Lett., 33, L16611, https://doi.org/10.1029/2006GL026817, 2006.

Jaeglé, L., Quinn, P. K., Bates, T. S., Alexander, B., and Lin, J.-T.: Global distribution of sea salt aerosols: new constraints from in situ and remote sensing observations, Atmos. Chem. Phys., 11, 3137-3157, https://doi.org/10.5194/acp-11-3137-2011, 2011.

Johnson, G., Ristovski, Z., and Morawska, L.: Application of the VH-TDMA technique to coastal ambient aerosols, Geophys. Res. Lett., 31, L16105, https://doi.org/10.1029/2004GL020126, 2004.

Jones, A. R., Thomson, D. J., Hort, M., and Devenish, B.: The UK Met Office's next-generation atmospheric dispersion model, NAME III, in: Proceedings of the 27th NATO/CCMS International Technical Meeting on Air Pollution Modelling and its Application, edited by: Borrego, C., and Norman, A.-L., Springer, 580-589, 2007.

Kay, J. E., Wall, C., Yettella, V., Medeiros, B., Hannay, C., Caldwell, P., and Bitz, C.: Global Climate Impacts of Fixing the Southern Ocean Shortwave Radiation Bias in the Community Earth System Model (CESM), J. Climate, 29, 4617-4636, https://doi.org/10.1175/JCLI-D-15-0358.1, 2016.

Kiene, R. P., Kieber, D. J., Slezak, D., Toole, D. A., del Valle, D. A., Bisgrove, J., Brinkley, J., and Rellinger, A.: Distribution and cycling of dimethylsulfide, dimethylsulfoniopropionate, and dimethylsulfoxide during spring and early summer in the Southern Ocean south of New Zealand, Aquat. Sci., 69, 305-319, https://doi.org/10.1007/s00027-007-0892-3, 2007.

Korhonen, H., Carslaw, K. S., Spracklen, D. V., Mann, G. W., and Woodhouse, M. T.: Influence of oceanic dimethyl sulfide emissions on cloud condensation nuclei concentrations and seasonality over the remote Southern Hemisphere oceans: A global model study, J. Geophys. Res.-Atmos., 113, D15204, https://doi.org/10.1029/2007jd009718, 2008.

Lana, A., Bell, T. G., Simo, R., Vallina, S. M., Ballabrera-Poy, J., Kettle, A. J., Dachs, J., Bopp, L., Saltzman, E. S., Stefels, J., Johnson, J. E., and Liss, P. S.: An updated climatology of surface dimethlysulfide concentrations and emission fluxes in the global ocean, Global Biogeochem. Cy., 25, GB1004, https://doi.org/10.1029/2010gb003850, 2011.

Lana, A., Simó, R., Vallina, S. M., and Dachs, J.: Potential for a biogenic influence on cloud microphysics over the ocean: a correlation study with satellite-derived data, Atmos. Chem. Phys., 12, 7977-7993, https://doi.org/10.5194/acp-12-7977-2012, 2012.

Landschuetzer, P., Gruber, N., Bakker, D. C. E., and Schuster, U.: Recent variability of the global ocean carbon sink, Global Biogeochem. Cy., 28, 927-949, https://doi.org/10.1002/2014gb004853, 2014. 
Landwehr, S., Miller, S. D., Smith, M. J., Saltzman, E. S., and Ward, B.: Analysis of the PKT correction for direct $\mathrm{CO}_{2}$ flux measurements over the ocean, Atmos. Chem. Phys., 14, 3361-3372, https://doi.org/10.5194/acp-14-3361-2014, 2014.

Landwehr, S., Miller, S. D., Smith, M. J., Saltzman, E. S., Bell, T. G., and Ward, B.: Using Eddy Covariance to Measure the Dependence of Air-Sea $\mathrm{CO}_{2}$ Exchange Rate on Friction Velocity, Atmos. Chem. Phys. Discuss, submitted, 2017.

Lawson, S. J., Selleck, P. W., Galbally, I. E., Keywood, M. D., Harvey, M. J., Lerot, C., Helmig, D., and Ristovski, Z.: Seasonal in situ observations of glyoxal and methylglyoxal over the temperate oceans of the Southern Hemisphere, Atmos. Chem. Phys., 15, 223-240, https://doi.org/10.5194/acp-15-223-2015, 2015.

Lawson, S. J., Selleck, P. W., Cheng, M., and Harvey, M.: VOCs in marine air over the biologically productive Chatham Rise, Atmos. Chem. Phys. Discuss., in preparation, 2017.

Lizotte, M., Levasseur, M., Law, C. S., Walker, C. F., Safi, K. A., Marriner, A., and Kiene, R. P.: Dimethylsulfoniopropionate (DMSP) and dimethylsulfide (DMS) cycling across contrasting biological hotspots of the New Zealand Subtropical Front, Ocean Sci. Discuss., https://doi.org/10.5194/os-2017-32, in review, 2017.

Longhurst A. : Ecological Geography of the Sea, Acad. Press, London, 1998

Mahajan, A. S., Prados-Roman, C., Hay, T. D., Lampel, J., Pöhler, D., Großmann, K., Tschritter, J., Frieß, U., Platt, U., Johnston, P., Kreher, K., Wittrock, F., Burrows, J. P., Plane, J. M. C., and Saiz-Lopez, A.: Glyoxal observations in the global marine boundary layer, J. Geophys. Res.-Atmos., 119, 6160-6169, https://doi.org/10.1002/2013JD021388, 2014.

Mahajan, A. S., Fadnavis, S., Thomas, M. A., Pozzoli, L., Gupta, S., Royer, S.-J., Saiz-Lopez, A., and Simó, R.: Quantifying the impacts of an updated global dimethyl sulfide climatology on cloud microphysics and aerosol radiative forcing, J. Geophys. Res.-Atmos., 120, 2524-2536, https://doi.org/10.1002/2014JD022687, 2015.

Mallet, M., Cravigan, L., Miljevic, B., Vaattovaara, P., Deschaseaux, E., Swan, H., Jones, G., and Ristovski, Z.: Sea spray aerosol in the Great Barrier Reef and the presence of nonvolatile organics, J. Geophys. Res.-Atmos., 121, 7088-709, https://doi.org/10.1002/2016JD024966, 2016.

Mann, G. W., Carslaw, K. S., Spracklen, D. V., Ridley, D. A., Manktelow, P. T., Chipperfield, M. P., Pickering, S. J., and Johnson, C. E.: Description and evaluation of GLOMAP-mode: a modal global aerosol microphysics model for the UKCA composition-climate model, Geosci. Model Dev., 3, 519-551, https://doi.org/10.5194/gmd-3-519-2010, 2010.

Mann, G. W., Carslaw, K. S., Ridley, D. A., Spracklen, D. V., Pringle, K. J., Merikanto, J., Korhonen, H., Schwarz, J. P., Lee, L. A., Manktelow, P. T., Woodhouse, M. T., Schmidt, A., Breider, T. J., Emmerson, K. M., Reddington, C. L., Chipperfield, M. P., and Pickering, S. J.: Intercomparison of modal and sectional aerosol microphysics representations within the same 3-D global chemical transport model, Atmos. Chem. Phys., 12, 4449-4476, https://doi.org/10.5194/acp-12-4449-2012, 2012.

Marandino, C. A., De Bruyn, W. J., Miller, S. D., and Saltzman, E. S.: DMS air/sea flux and gas transfer coefficients from the North Atlantic summertime coccolithophore bloom, Geophys.
Res. Lett., 35, L23812, https://doi.org/10.1029/2008g1036370, 2008.

McCoy, D. T., Burrows, S. M., Wood, R., Grosvenor, D. P., Elliott, S. M., Ma, P.-L., Rasch, P. J., and Hartmann, D. L.: Natural aerosols explain seasonal and spatial patterns of Southern Ocean cloud albedo, Sci. Adv., 1, e1500157, https://doi.org/10.1126/sciadv.1500157, 2015.

Meskhidze, N. and Nenes, A.: Phytoplankton and cloudiness in the Southern Ocean, Science, 314, 1419-1423, 2006.

Meskhidze, N. and Nenes, A.: Effects of Ocean Ecosystem on Marine Aerosol-Cloud Interaction, Adv. Meteorol., 2010, 239808 , https://doi.org/10.1155/2010/239808, 2010.

Meskhidze, N., Xu, J., Zhang, Y., Gantt, B., Ghan, S., Nenes, A., Liu, X., Easter, R., and Zaveri, R.: Effect of marine biogenic organic aerosols on cloud properties: Modeling study, Geochim. Cosmochim. Ac., 73, p. A874, 2009.

Meskhidze, N., Xu, J., Gantt, B., Zhang, Y., Nenes, A., Ghan, S. J., Liu, X., Easter, R., and Zaveri, R.: Global distribution and climate forcing of marine organic aerosol: 1. Model improvements and evaluation, Atmos. Chem. Phys., 11, 11689-11705, https://doi.org/10.5194/acp-11-11689-2011, 2011.

Modini, R. L., Harris, B., and Ristovski, Z. D.: The organic fraction of bubble-generated, accumulation mode Sea Spray Aerosol (SSA), Atmos. Chem. Phys., 10, 2867-2877, https://doi.org/10.5194/acp-10-2867-2010, 2010.

Murphy, R. J., Pinkerton, M. H., Richardson, K. M., BradfordGrieve, J. M., and Boyd, P. W.: Phytoplankton distributions around New Zealand derived from SeaWiFS remotely-sensed ocean colour data, New Zeal. J. Mar. Fresh., 35, 343-362, 2001.

Nightingale, P. D., Malin, G., Law, C. S., Watson, A. J., Liss, P. S., Liddicoat, M. I., Boutin, J., and Upstill-Goddard, R. C.: In situ evaluation of air-sea gas exchange parameterizations using novel conservative and volatile tracers, Global Biogeochem. Cy., 14, 373-387, 2000.

Nodder, S. D., Duineveld, G. C. A., Pilditch, C. A., Sutton, P. J., Probert, P. K., Lavaleye, M. S. S., Witbaard, R., Chang, F. H., Hall, J. A., and Richardson, K. M.: Focusing of phytodetritus deposition beneath a deep-ocean front, Chatham Rise, New Zealand, Limnol. Oceanogr., 52, 299-314, 2007.

O'Dowd, C., Monahan, C., and Dall'Osto, M.: On the occurrence of open ocean particle production and growth events, Geophys. Res. Lett., 37, L19805, https://doi.org/10.1029/2010g1044679, 2010.

O’Dowd, C. D. and de Leeuw, G.: Marine aerosol production: a review of the current knowledge, Philos. T. R. Soc. A., 365, 1753 1774, 2007.

O'Dowd, C. D., Facchini, M. C., Cavalli, F., Ceburnis, D., Mircea, M., Decesari, S., Fuzzi, S., Yoon, Y. J., and Putaud, J.-P.: Biogenically driven organic contribution to marine aerosol, Nature, 431, 676-680, 2004.

Popinet, S., Smith, M., and Stevens, C.: Experimental and Numerical Study of the Turbulence Characteristics of Airflow around a Research Vessel, J. Atmos. Ocean. Tech., 21, 1575-1589, https://doi.org/10.1175/15200426(2004)021<1575:EANSOT>2.0.CO;2, 2004.

Quinn, P. K. and Bates, T. S.: The case against climate regulation via oceanic phytoplankton sulphur emissions, Nature, 480, 5156, 2011.

Quinn, P. K., Bates, T. S., Schulz, K. S., Coffman, D. J., Frossard, A. A., Russell, L. M., Keene, W. C., and Kieber, D. J.: Contribution 
of sea surface carbon pool to organic matter enrichment in sea spray aerosol, Nat. Geosci., 7, 228-232, 2014.

Rinaldi, M., Fuzzi, S., Decesari, S., Marullo, S., Santoleri, R., Provenzale, A., von Hardenberg, J., Ceburnis, D., Vaishya, A., O'Dowd, C. D., and Facchini, M. C.: Is chlorophyll-a the best surrogate for organic matter enrichment in submicron primary marine aerosol?, J. Geophys. Res.-Atmos., 118, 4964-4973, https://doi.org/10.1002/jgrd.50417, 2013.

Russell, L. M., Hawkins, L. N., Frossard, A. A., Quinn, P. K., and Bates, T. S.: Carbohydrate-like composition of submicron atmospheric particles and their production from ocean bubble bursting, P. Natl. Acad. Sci. USA, 107, 6652-6657, https://doi.org/10.1073/pnas.0908905107, 2010.

Russell, L. M., Bahadur, R., and Ziemann, P. J.: Identifying organic aerosol sources by comparing functional group composition in chamber and atmospheric particles, P. Natl. Acad. Sci. USA, 108.9, 3516-3521, 2011.

Sadeghi, A., Dinter, T., Vountas, M., Taylor, B. B., AltenburgSoppa, M., Peeken, I., and Bracher, A.: Improvement to the PhytoDOAS method for identification of coccolithophores using hyper-spectral satellite data, Ocean Sci., 8, 1055-1070, https://doi.org/10.5194/os-8-1055-2012, 2012.

Scanlon, B. and Ward, B.: The influence of environmental parameters on active and maturing oceanic whitecaps, J. Geophys. Res.Oceans, 121, 8:1-12, https://doi.org/10.1002/2015JC011230, 2016.

Seinfeld, J. H., Bretherton, C., Carslaw, K. S., Coe, H., DeMott, P. J., Dunlea, E. J., Feingold, G., Ghan, S., Guenther, A. B., Kahn, R., Kraucunas, I., Kreidenweis, S. M., Molina, M. J., Nenes, A., Penner, J. E., Prather, K. A., Ramanathan, V., Ramaswamy, V., Rasch, P. J., Ravishankara, A. R., Rosenfeld, D., Stephens, G., and Wood, R.: Improving our fundamental understanding of the role of aerosol-cloud interactions in the climate system, P. Natl. Acad. Sci. USA, 113, 5781-5790, https://doi.org/10.1073/pnas.1514043113, 2016.

Sellegri, K., Loon, Y. J., Jennings, S. G., O’Dowd, C. D., Pirjola, L., Cautenet, S., Chen, H. W., and Hoffmann, T.: Quantification of coastal new ultra-fine particles formation from in situ and chamber measurements during the BIOFLUX campaign, Environ. Chem., 2, 260-270, https://doi.org/10.1071/en05074, 2005.

Sievering, H., Cainey, J., Harvey, M., McGregor, J., Nichol, S., and Quinn, P.: Aerosol non-sea-salt sulfate in the remote marine boundary layer under clear-sky and normal cloudiness conditions: Ocean-derived biogenic alkalinity enhances sea-salt sulfate production by ozone oxidation, J. Geophys. Res.-Atmos., 109, D19317, https://doi.org/10.1029/2003jd004315, 2004.

Smith, M. J., Ho, D. T., Law, C. S., McGregor, J., Popinet, S., and Schlosser, P.: Uncertainties in gas exchange parameterization during the SAGE dual-tracer experiment, Deep-Sea Res. Pt. II, 58, 869-881, https://doi.org/10.1016/j.dsr2.2010.10.025, 2011.

Smith, M. J., Walker, C. F., Bell, T. G., Harvey, M. J., Law, C. S., and Saltzman, E. S.: Gradient flux measurements of sea-air DMS transfer during the Surface Ocean Aerosol Production (SOAP) experiment, Atmos. Chem. Phys. Discuss., submitted, 2017.

Spada, M., Jorba, O., Pérez García-Pando, C., Janjic, Z., and Baldasano, J. M.: On the evaluation of global sea-salt aerosol models at coastal/orographic sites, Atmos. Environ., 101, 41-48, https://doi.org/10.1016/j.atmosenv.2014.11.019, 2015.
Stephens, G. L.: Cloud feedbacks in the climate system: A critical review, J. Climate, 18, 237-273, 2005.

Stevens, C. L., Hill, P., Smith, M. J., and Popinet, S.: SUCA: An engine for repetitive autonomous profiling near the ocean surface, Limnol. Oceanogr.-Meth., 3, 300-307, 2005.

Swan, H. B., Armishaw, P., Lavetz, R., Alamgir, M., Davies, S. R., Bell, T. G., and Jones, G. B.: An interlaboratory comparison for the quantification of aqueous dimethylsulfide, Limnol. Oceanogr.-Meth., 12, 784-794, https://doi.org/10.4319/lom.2014.12.784, 2014.

Thomas, M. A., Suntharalingam, P., Pozzoli, L., Rast, S., Devasthale, A., Kloster, S., Feichter, J., and Lenton, T. M.: Quantification of DMS aerosol-cloud-climate interactions using the ECHAM5-HAMMOZ model in a current climate scenario, Atmos. Chem. Phys., 10, 7425-7438, https://doi.org/10.5194/acp10-7425-2010, 2010.

Trenberth, K. E. and Fasullo, J. T.: Simulation of present-day and twenty-first-century energy budgets of the southern oceans, J. Climate, 23, 440-454, 2010.

Twomey, S.: The influence of pollution on the shortwave albedo of clouds, J. Atmos. Sci., 34, 1149-1152, 1977.

Vaattovaara, P., Räsänen, M., Kühn, T., Joutsensaari, J., and Laaksonen, A.: A method for detecting the presence of organic fraction in nucleation mode sized particles, Atmos. Chem. Phys., 5, 3277-3287, https://doi.org/10.5194/acp-5-3277-2005, 2005.

Vaattovaara, P., Huttunen, P. E., Yoon, Y. J., Joutsensaari, J., Lehtinen, K. E. J., O'Dowd, C. D., and Laaksonen, A.: The composition of nucleation and Aitken modes particles during coastal nucleation events: evidence for marine secondary organic contribution, Atmos. Chem. Phys., 6, 4601-4616, https://doi.org/10.5194/acp-6-4601-2006, 2006.

Vaishya, A., Jennings, S. G., and O'Dowd, C.: Winddriven influences on aerosol light scattering in northeast Atlantic air, Geophys. Res. Lett., 39, L05805, https://doi.org/10.1029/2011GL050556, 2012.

Vallina, S. M., Simó, R., and Gassó, S.: What controls CCN seasonality in the Southern Ocean? A statistical analysis based on satellite-derived chlorophyll and $\mathrm{CCN}$ and model-estimated $\mathrm{OH}$ radical and rainfall, Global Biogeochem. Cy., 20, GB1014, https://doi.org/10.1029/2005GB002597, 2006.

Vignati, E., Facchini, M. C., Rinaldi, M., Scannell, C., Ceburnis, D., Sciare, J., Kanakidou, M., Myriokefalitakis, S., Dentener, F., and O'Dowd, C. D.: Global scale emission and distribution of seaspray aerosol: Sea-salt and organic enrichment, Atmos. Environ., 44, 670-677, 2010.

Villani, P., Picard, D., Michaud, V., Laj, P., and Wiedensohler, A.: Design and Validation of a Volatility Hygroscopic Tandem Differential Mobility Analyzer (VH-TDMA) to Characterize the Relationships Between the Thermal and Hygroscopic Properties of Atmospheric Aerosol Particles, Aerosol Sci. Technol., 42, 729741, https://doi.org/10.1080/02786820802255668, 2008.

Walker, C. F., Harvey, M. J., Smith, M. J., Bell, T. G., Saltzman, E. S., Marriner, A. S., McGregor, J. A., and Law, C. S.: Assessing the potential for dimethylsulfide enrichment at the sea surface and its influence on air-sea flux, Ocean Sci., 12, 1033-1048, https://doi.org/10.5194/os-12-1033-2016, 2016.

Wang, H., Easter, R. C., Rasch, P. J., Wang, M., Liu, X., Ghan, S. J., Qian, Y., Yoon, J.-H., Ma, P.-L., and Vinoj, V.: Sensitivity of remote aerosol distributions to representation of cloud-aerosol 
interactions in a global climate model, Geosci. Model Dev., 6, 765-782, https://doi.org/10.5194/gmd-6-765-2013, 2013.

Willis, M. D., Burkart, J., Thomas, J. L., Köllner, F., Schneider, J., Bozem, H., Hoor, P. M., Aliabadi, A. A., Schulz, H., Herber, A. B., Leaitch, W. R., and Abbatt, J. P. D.: Growth of nucleation mode particles in the summertime Arctic: a case study, Atmos. Chem. Phys., 16, 7663-7679, https://doi.org/10.5194/acp16-7663-2016, 2016.

Woodhouse, M. T., Luhar, A. K., Stevens, L., Galbally, I., Thatcher, M., Uhe, P., Wolff, H., Noonan, J., and Molloy, S.: Australian reactive-gas emissions in a global chemistry-climate model and initial results, Air Quality and Climate Change, 49, 31-38, 2015.

Wylie, D. J. and de Mora, S. J.: Atmospheric dimethylsulfide and sulfur species in aerosol and rainwater at coastal site in New Zealand, J. Geophys. Res., 101, 21041-21049, 1996.
Yang, M., Blomquist, B. W., Fairall, C. W., Archer, S. D., and Huebert, B. J.: Air-sea exchange of dimethylsulfide in the Southern Ocean: Measurements from SO GasEx compared to temperate and tropical regions, J. Geophys. Res., 116, C00F05, https://doi.org/10.1029/2010JC006526, 2011.

Young, I. R., Vinoth, J., Zieger, S., and Babanin, A. V.: Investigation of trends in extreme value wave height and wind speed, J. Geophys. Res.-Oceans, 117, C00J06, https://doi.org/10.1029/2011JC007753, 2012.

Zhang, R.: Getting to the Critical Nucleus of Aerosol Formation, Science, 328, 1366-1367, https://doi.org/10.1126/science.1189732, 2010. 